\title{
Potentiality of the Use of Pyroclastic Volcanic Residues in the Production of Alkali Activated Material
}

\author{
Germana Barone $^{1} \cdot$ Claudio Finocchiaro $^{1} \cdot$ Isabella Lancellotti ${ }^{2}(1) \cdot$ Cristina Leonelli $^{2} \cdot$ Paolo Mazzoleni $^{1}$. \\ Caterina Sgarlata ${ }^{2} \cdot$ Antonio Stroscio $^{1}$
}

Received: 11 October 2019 / Accepted: 7 March 2020 / Published online: 27 March 2020

(c) The Author(s) 2020

\begin{abstract}
Volcanic rocks have been used for building activity by the inhabitants of important cities located on the slopes of Mt. Etna, Italy. In this paper, the potential use of volcanic residues (code 2003 03-"Municipal waste" residues from road cleaning in the European Waste Catalogue (EWC)) for the production of alkali activated material, especially devoted to the restoration of buildings belonging to the Baroque Sicilian architecture, was investigated. In particular, large volcanic pyroclastic deposits of recent eruptions considered waste materials were studied and a volcanic paleo-soil, locally named ghiara, widely used for mortars and plaster production in XVII-XVIII century with good pozzolanic features, was also considered. Both volcanic materials were activated using different mixtures of $\mathrm{NaOH}$ and $\mathrm{Na}_{2} \mathrm{SiO}_{3}$. Furthermore, formulations with different amount of metakaolin addition (10-25 wt \%) were prepared due to low reactivity of volcanic materials and to allow the activation at room temperature. $\mathrm{X}$ ray diffraction revealed the formation of small quantities of zeolites as a result of the alkali activation process. The mechanical-physical results evidenced that the mechanical strength is strongly dependent on the metakaolin amount (10-38 MPa); accessible porosity average $25 \%$ and an average pore diameter of $0.06 \mu \mathrm{m}$; water absorption range $9-15 \%$, eluates conductivity in the range $20-350 \mu \mathrm{S} / \mathrm{m}$. These results confirm the occurring of alkali activation and the good potential for these pyroclastic wastes for valorization in the restoration field.
\end{abstract}

Electronic supplementary material The online version of this article (https://doi.org/10.1007/s12649-020-01004-6) contains supplementary material, which is available to authorized users.

Extended author information available on the last page of the article 


\section{Graphic Abstract}

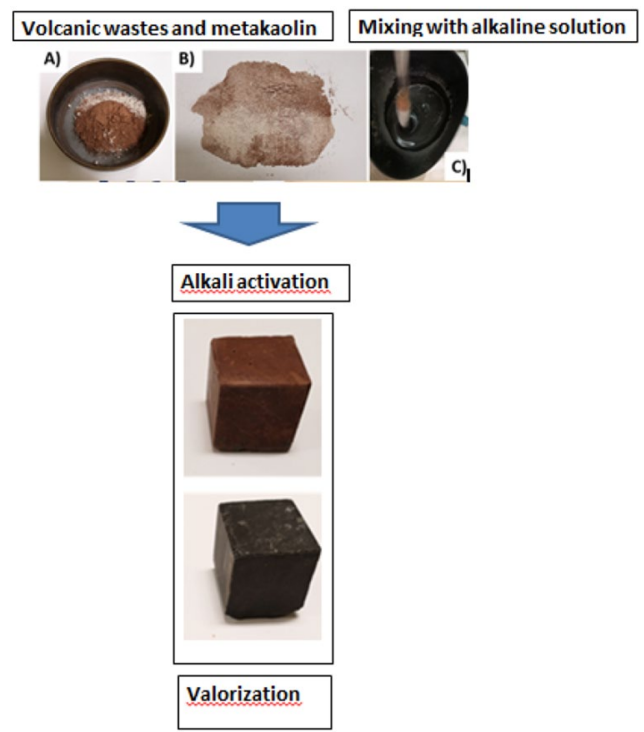

Keywords Waste valorization · Volcanic precursors $\cdot$ Recycling $\cdot$ Alkaline activation $\cdot$ Conservation

\section{Statement of Novelty}

The novelty of this study is the valorization of a local paleosoil, ghiara, to obtain alkaline activated materials and their characterization. Notwithstanding volcanic ash are already reported in literature for alkaline activation, ghiara paleosoil has not yet been investigated as resource for building materials. The concept of using low cost additives, as metakaolin in the proposed case, in the formulations allows the consolidation to occur without any thermal treatment, thus the formulated materials can be use in situ in the cultural heritage/restoration field.

\section{Introduction}

The close relationship between architecture and raw materials provided by the geology of a territory is well-known [1]. This is particularly evident in the area of Catania, Italy, where, since prehistoric times, the rocks coming from Mt. Etna eruptive activity have been used [2-4]. Mt. Etna volcano covers an area of $1250 \mathrm{~km}^{2}$ in the eastern Sicily, Italy (Fig. 1). It represents the highest volcano in Europe and one of the most active basaltic strato-volcanoes in the world, where both summit and flank eruptions occur very often, strongly influencing the densely populated territory. Historically, volcanic materials were mainly used as aggregates for the production of mortars and plasters. Indeed, the historical buildings of Etnean area are characterized by dark grey mortars for the use of pyroclastic rocks, while red hue for the use of the so-called "ghiara".

This latter is a paleo-soils characterized by a reddish hue due its high iron content combined with the high temperatures $\left(800-900{ }^{\circ} \mathrm{C}\right)$ and oxidising conditions reached in contact with the overlying lava flow (Fig. 2). Generally, the layer of "ghiara" paleo-soils has a thickness ranging from few centimetres to about $1 \mathrm{~m}$, and is macroscopically heterogeneous, since its aspect reproduces the origin of the sediments involved by the overflowing lava, deriving from epyclastic or pyroclastic deposits [5]. The grain size of these paleo-soils is variable, but the ghiara deposits used as mortars aggregates are formed by prevailing sandy-silty granulometric fraction. Its volcanic origin is a peculiar feature of the Etnean area and it is found nowhere else in the world. Indeed, this material was extracted for a long time in different anthropic cavities (tunnels also several kilometres long), located in Etnean territory, to be used as aggregate in Catania architecture in the seventeenth and eighteenth centuries in mortar and plaster production (Fig. 3a, b).

Worthy of note is the fact that the use of pyroclastic rocks in the mortars is limited to the old leached deposits, since the fresh volcanic products have an excessively high chlorides and sulphates content due to their interaction with the volcanic gasses [6]. In this scenario, the thick pyroclastic deposits produced by the recent frequent explosive activity of Mt. Etna cannot be used in the traditional cement industry.

The purpose of our research is to investigate the potential valorization of pyroclastic volcanic products and ghiara as 


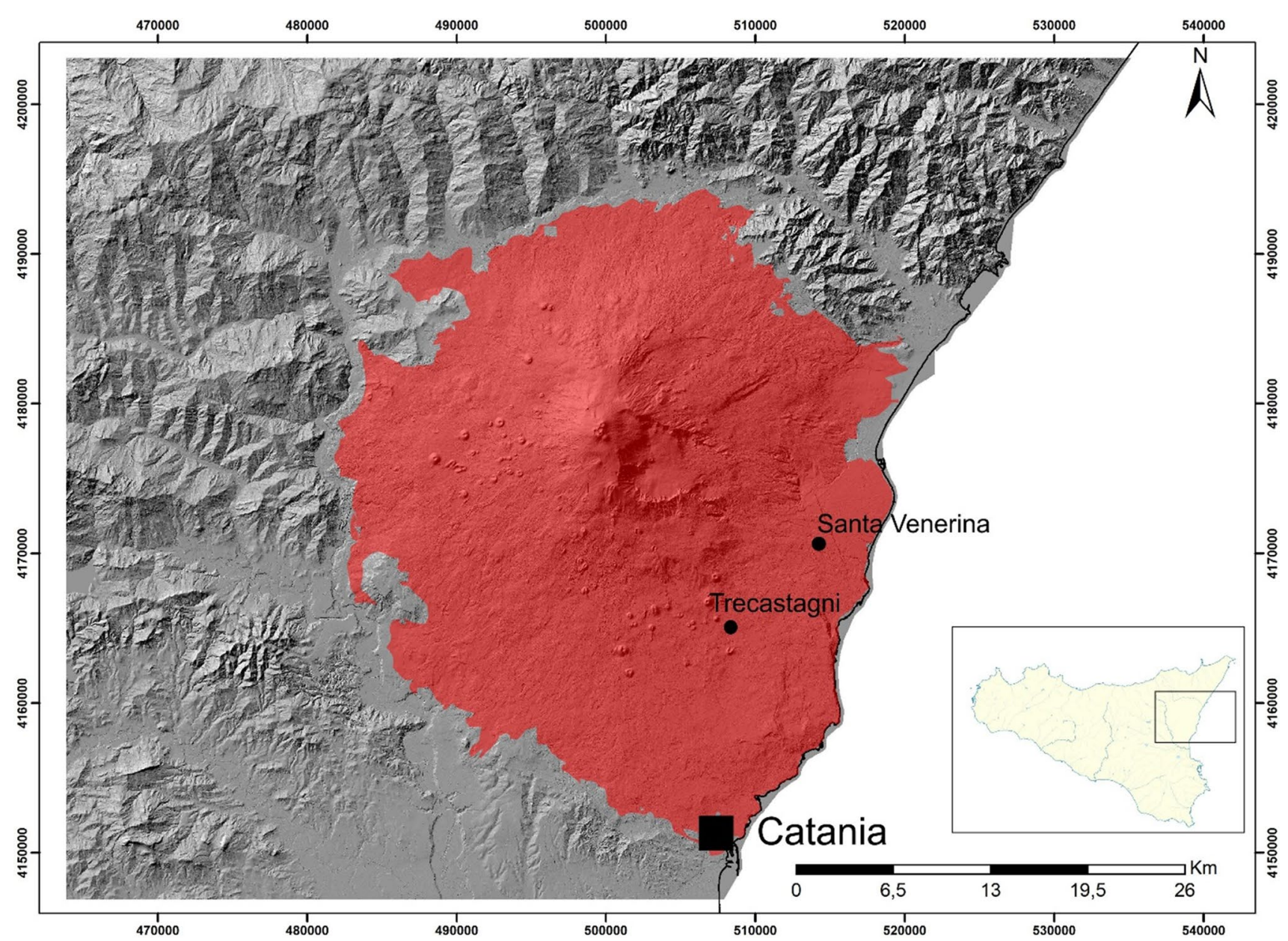

Fig. 1 Geological map of Mt. Etna volcano, Sicily, Italy

Fig. 2 Ghiara quarry (Mt. Etna, Italy): the dashed line divides the ancient volcanic soil with the 1408 lava flow

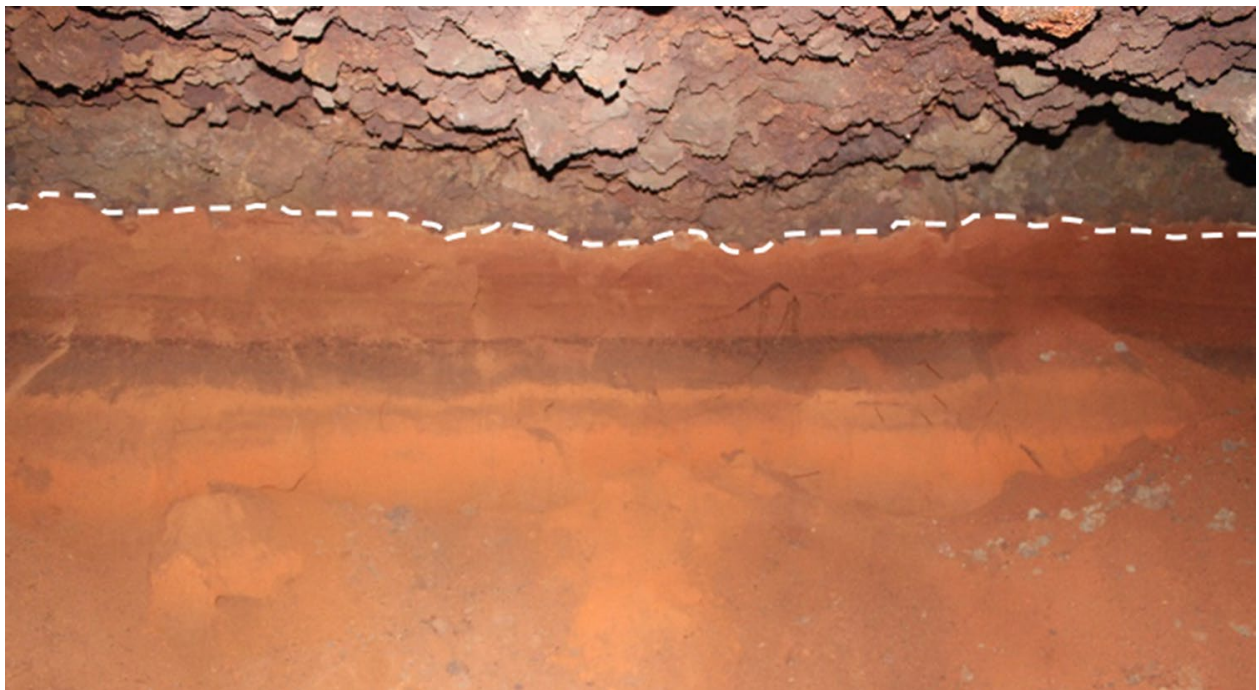

raw material for alkali activated material (AAM), also with the aim to reproduce ancient mortars for the restoration of historical monuments and buildings.
In particular, we tested ghiara as precursor for AAMs production with the aim to overcome durability problems caused by use of traditional Ordinary Portland Cement based 


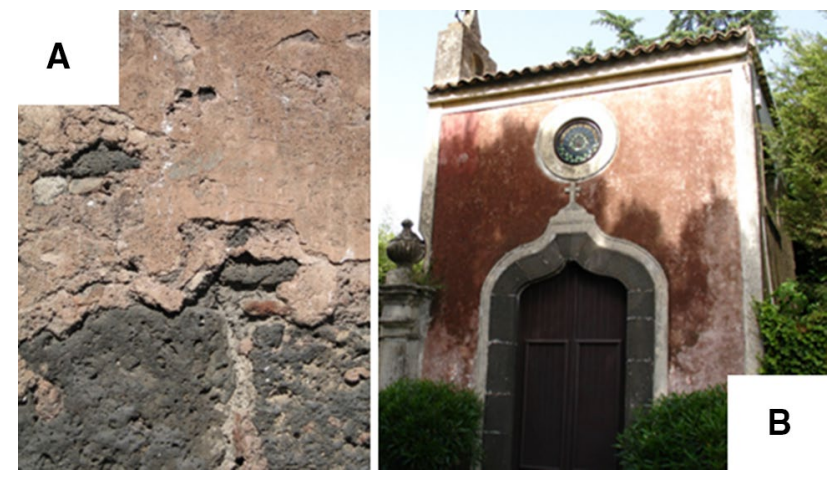

Fig. 3 a Detachment of mortar based on ghiara; b Original plaster application in San Salvatore church in Viagrande, Catania, Italy

mortars (e.g. detachments) in the restoration works of historical buildings characterised by reddish façades and mortar.

At the moment, pyroclastic particles, once erupted and deposited on ground, are classified as waste with code 20 03 03- "Municipal waste" residues from road cleaning in the European Waste Catalogue (EWC). However, on March 2014, the waste code was temporarily modified in "Soil and Rock-excavated" (code 1705 04) after a significant eruption of volcano Etna, occurred on March 2013 [7]. At this purpose, our work is also motivated by the absence of normative references regarding the management of this natural "resource". Therefore, the use of volcanic pyroclastic wastes for the production of AAMs represents an opportunity for the economic development of this territory, a good alternative to traditional building materials and an improvement of their management.

In the last decades, scientific literature reports the preparation of AAMs with different natural and waste raw materials mostly to reduce $\mathrm{CO}_{2}$ emission produced in traditional materials industry, such as cement or bricks [8-15]. These materials are aluminosilicate polymers, also called "geopolymers", characterized by good mechanical and chemical properties, obtained by reaction of an aluminosilicate material with an alkaline solution [16, 17]. They have several application fields, such as building materials and hazardous waste encapsulation, guaranteeing high strength, low shrinkage, low carbon emission, acid resistance, etc. [18-20]. However, their properties depend on many factors among which: typology of precursor materials, mineralogical and chemical composition of the aluminosilicate sources, particle size distribution of the raw material, curing temperature, composition of the alkaline solution and liquid to solid ratio [21]. Alkali synthesis involves a three steps process made of dissolution of aluminosilicate raw material in high $\mathrm{pH}$ solution composed by alkali activators, followed by room temperature polymerisation of active surface groups and soluble species to form a gel, then subsequently polycondensation to form hardened three dimensional structures
[22]. In particular, dissolution rate of the aluminium and silicon species depends on the amorphous nature of the precursor materials as well as the fineness of powder particles. Geopolymer structure is made of complex polymeric chains of connected $\mathrm{SiO}_{4}$ and $\mathrm{AlO}_{4}$ tetrahedra $[23,24]$ linked by shared oxygen atoms, with alkali cations $\left(\mathrm{Na}^{+}, \mathrm{K}^{+}, \mathrm{Ca}^{2+}\right.$, etc.) from the activator solution present to balance the negative charge of tetrahedrally coordinated $\mathrm{Al}^{3+}$.

In this context, volcanic glass is one of the most suitable materials for AAMs production. Subsequently, it was used as precursor for alkali activation synthesis [17, 20, 25]. However, the higher stability in high alkaline environment of volcanic glass when compared to the more commonly used geopolymers materials, such as metakaolin and fly ashes, required thermal treatments to positively influence the final properties of AAM as evidenced in literature (e.g. [24].). This thermal treatment together with long setting time, high shrinkage and excess efflorescence strongly limited their application as a building material.

The final goal of our study is evaluating the use of Mt. Etna pyroclastic wastes to produce low cost building materials suitable also for restoration of areas of cultural heritage damage. The alkali activation was chosen among the different possibilities of valorization [26] since it repeats the ancient construction procedures and maintains the original colours, morphologies, expansion, and vapour permeability of the old/ancient buildings. Several formulations of alkali activated materials containing volcanic ash or ghiara were tested with and without addition of metakaolin. The characterization proposed in this paper is focused on evaluating chemical and mechanical stability of the consolidated material, as well as its durability $[27,28]$.

The proposed procedure shows regional benefits in economic and environmental terms thanks to a sustainable management of pyroclastic deposits with a recycling at $\mathrm{km}$ 0 , and represents a successful initiative in ancient building restoration starting from local raw materials.

\section{Materials and Methods}

The volcanic explosive activity produces pyroclastic particles normally distinguished into three main categories on the basis of their grain size: bomb (>64 mm), lapilli (64-2 mm) and ash $(<2 \mathrm{~mm})$ [29]. Going forward, we indicate with the term volcanic ash both categories of lapilli and ash. The pyroclastic particles used in this study were sampled near the Santa Venerina town (in the south-east slope of Mt. Etna volcano, Italy) after the 03/16/2013 eruption. The dimensional sorting of the particles of the pyroclastic deposits was low ranging from $2 \mathrm{~cm}$ to $0.1 \mathrm{~mm}$, hence they could be defined volcanic ash. The samples were collected, according to international recommendations [30], at the same time or 
shortly after deposition. Special care was taken to prevent the contamination of the volcanic material with other natural (e.g., dust or ash from previous eruptions) or anthropic particulates. Furthermore, the samples have not been in contact with water either during deposition or after the sampling.

Ghiara samples were collected in the "Orcio" quarry, located in the district of Trecastagni village (in the south slope of Mt. Etna), Italy. It is one of the largest anthropic cavities of Etnean area, mainly used in ancient time for the extraction of this red paleo-soils. The deposit has a variable thickness $(1.20-1.60 \mathrm{~m})$ and is characterized by a grain size between 2 and $0.5 \mathrm{~mm}$. Ghiara colour changes from yellowish hue near the contact with the lava roof, to brick-reddish hue in the deposit's core (see onward in the text for colour assessment).

Once the moisture was dried and removed, both materials were dry milled and sieved to obtain a grain size $<75 \mu \mathrm{m}$, dimension which was considered suitable for the alkali activation process [31].

For alkali formulation without thermal treatments (series VM and GM for volcanic ash and ghiara, respectively), we also used the addition of 5-25\% of ARGICAL ${ }^{\text {TM }}$ M1000 metakaolin, (IMERYS, France, reported chemical composition from producer: $\mathrm{SiO}_{2}=55 \% ; \mathrm{Al}_{2} \mathrm{O}_{3}=40 \%, \mathrm{Fe}_{2} \mathrm{O}_{3}=1.4 \%$; $\mathrm{TiO}_{2}=1.5 \% ; \mathrm{Na}_{2} \mathrm{O}+\mathrm{K}_{2} \mathrm{O}=0.8 \% ; \mathrm{CaO}+\mathrm{MgO}=0.3 \%$; $\mathrm{LOI}=1 \%)$.

Regarding activators, sodium hydroxide ( $8 \mathrm{M})$ and two sodium silicates were used. Specifically, a pure sodium silicate (provided by Carlo Erba, Milan, Italy) (code: 373,908) with ratio $\mathrm{SiO}_{2} / \mathrm{Na}_{2} \mathrm{O}=2$ and a liquid sodium silicate (provided by Ingessil s.r.l., Verona, Italy) with a molar ratio $\mathrm{SiO}_{2} / \mathrm{Na}_{2} \mathrm{O}=3$.

After 7 days of curing, in order to obtain an immediate feedback, an "integrity test" was performed on all AAM samples to check the chemical stability and preliminary resistance to mechanical stress [31]. The test consisted of the immersion of the sample in de-ionized water with a solid/ liquid ratio of $1 / 10$. After $24 \mathrm{~h}$, the sample integrity was visually evaluated in terms of dimensional changes, surface modifications and water color.

Mineralogical characterization was carried out only on the samples that are undamaged after this test. In detail, the $\mathrm{X}$ ray powder diffraction (XRD) analysis was performed on powdered samples after seven days of aging using a Siemens D5000 diffractometer, with $\mathrm{Cu} \mathrm{K} \alpha$ radiation and $\mathrm{Ni}$ filter, in the $2 \theta$ range $3-70^{\circ}$, using a step size of $0.02^{\circ}$, a counting time of $5 \mathrm{~s}$ for step, divergence and antiscatter slit of $1^{\circ}$ and receiving slit of $0.2 \mathrm{~mm}$. The quantitative data were obtained with Rietveld method using GSASII software [32]. The amorphous abundance was calculated by means of internal corundum standard addition [33].

$\mathrm{X}$ ray fluorescence spectroscopy (XRF) analysis was carried out on raw materials after grinding using a PHILIPS
PW2404 spectrometer on powder-pressed pellets; total loss on ignition (LOI) was gravimetrically estimated after overnight heating at $950{ }^{\circ} \mathrm{C}$. The quantitative analysis was carried out using a calibration line based on 45 international rocks standards. The limits of detection (LOD) were: $\mathrm{SiO}_{2}=1$ $\mathrm{wt} \%, \mathrm{TiO}_{2}=0.01 \mathrm{wt} \%, \mathrm{Al}_{2} \mathrm{O}_{3}=0.1 \mathrm{wt} \%, \mathrm{Fe}_{2} \mathrm{O}_{3}=0.05$ $\mathrm{wt} \%, \mathrm{MnO}=0.01 \mathrm{wt} \%, \mathrm{MgO}=0.02 \mathrm{wt} \%, \mathrm{CaO}=0.05 \mathrm{wt} \%$, $\mathrm{Na}_{2} \mathrm{O}=0.01 \mathrm{wt} \%, \mathrm{~K}_{2} \mathrm{O}=0.05 \mathrm{wt} \%, \mathrm{P}_{2} \mathrm{O}_{5}=0.01$. The precision was monitored by routinely running a well-investigated in-house standard (obsidian). The average relative standard deviations (RSD) were less than 5\%. Finally, the accuracy was evaluated using an international standard that is compositionally similar to the analysed samples. The accuracy was good for major elements $(<3 \%)$, except MnO. In detail, both on ghiara and on volcanic ash, five XRF measurements for major and trace elements were performed and the final results were obtained from their average values.

To evaluate the effective permeable porosity of representative AAMs belonging to series VM1 and GM1 (with 10, 20 $\mathrm{wt} \%$ metakaolin), permeable porosity test for total absorption were performed. The test was conducted on small cubic samples dried in an oven at temperature of $100{ }^{\circ} \mathrm{C}$ for $24 \mathrm{~h}$ to ensure that a constant mass was achieved. The specimens were left at room temperature in a desiccator for two hours to allow the cooling and to obtain their initial weight $\left(\mathrm{w}_{\mathrm{d}}\right)$. Afterwards, they were immersed in distilled water at room temperature and covered by $2 \mathrm{~cm}$ of water. The samples, once swabbed with a damp cloth, were weighed at various time intervals (starting to $1 \mathrm{~min}$ up to few hours). The test was considered ended once no recorded significant variation of wet mass $\left(<1 \% \mathrm{w}_{\mathrm{w}}\right)$ between two following measurements. Water absorption was then quantified using Eq. (1) to quantify the change of weight as percentage of the initial one.

Water absorption, $\%=\frac{w_{w}-w_{d}}{w_{d}} \times 100$

The investigation at sub-micrometric dimensional scale was carried out by $\mathrm{Hg}$ intrusion porosimetry (MIP) on small sherds of following samples: VM1-10, 20 and $20 L S$ and the equivalents for ghiara once removed humidity in the oven at $100{ }^{\circ} \mathrm{C}$ temperature. Moreover, specimens aged one year of the same formulations were analysed with the aim to compare them with the shards of cubic samples aged 5 months. Porosimetric analysis was carried out with a Thermoquest Pascal 240 macropore unit in order to explore a porosity range $\sim 0.0074 \mu \mathrm{m}<\mathrm{r}<\sim 15 \mu \mathrm{m}$ ( $\mathrm{r}$ being the radius of the pores), and by a Thermoquest Pascal 140 porosimeter instrument in order to investigate a porosity range from $\sim 3.8 \mu \mathrm{m}<\mathrm{r}<\sim 116 \mu \mathrm{m}$.

To assess the chemical stability of the material in the aqueous environment and to evaluate the efficacy of the 
consolidation process via alkali activation, the $\mathrm{pH}$ and the ionic conductivity measurements were carried out on the solutions produced at $25{ }^{\circ} \mathrm{C}$ immersing in de-ionized water five formulations belonging to the VM1 and GM1 series and containing $10-25 \%$ of metakaolin.

To perform $\mathrm{pH}$ tests it was used a Laboratory PH sensor Hamilton type Liq- glass SL, and it was measured with OAKTON Eutech Instruments Ph5/6 and Ion 6. Electrical conductivity was measured with OAKTON Eutech Instruments CON 6/TDS 6 . This test was performed after 28 days of curing at room temperature and consisted of the immersion of a solid piece of sample in distilled water, with a solid/liquid ratio of $1 / 10$ stirring for $24 \mathrm{~h}$ in a beaker. Measurements were determined for different times $0,5,15,30$, $60,120,720,1440 \mathrm{~min}$. Adopting such a procedure it is possible to monitor the changes over the first $24 \mathrm{~h}$ of the test and provide information on the amount of dissolved solid.

Morphological analyses were performed using a Tescan Vega LMU scanning electron microscope (SEM), equipped with a with EDAX energy dispersive spectrometer (EDS). Data were collected using a voltage of $20 \mathrm{kV}$ and a beam current of $0.2 \mathrm{nA}$. The measurements were performed on thin sections of samples fixed on a metal support and coated with a thin layer of graphitic carbon. SEM-EDS analysis were performed on two AAMs based on volcanic precursors plus 10 and $20 \mathrm{wt} \%$ of metakaolin, respectively, considered as representative of the VM1 and GM1 series, with the aim to highlight morphological and compositional features of microstructure whose characterize this type of material. Four images for each sample at low magnifications were taken to evaluate the main features of texture as whole porosity and general discontinuities (images as supplementary files), while different spot analysis were collected on small areas (high magnification) to estimate the chemical composition.

Mechanical compressive tests after 28 days of curing at room temperature were carried out on five formulations belonging to the VM1 and GM1 series with 10-25\% of metakaolin, including a "green" formulation (labelled with suffix LS), developed to reduce at minimum the use of sodium silicate solution with $20 \%$ of metakaolin addition. In this way, we can underline the influence of metakaolin on the final strength and to evaluate the effect of reducing the sodium silicate in alkaline solution, maintaining constant the other variables at the expense of workability. Compressive strength was determined using an Instron 5567 Universal Testing Machine with $30 \mathrm{kN}$ load limit and displacement of $3 \mathrm{~mm} / \mathrm{min}$ according to the standard UNI EN 826. In particular, four specimens for each formulation were prepared in cubic plastic moulds with a side of $2 \mathrm{~cm}$ (Fig. 4).

\section{Geopolymerization Process}

Volcanic materials powders with $<75 \mu \mathrm{m}$ grain size were mixed with different alkali solutions to obtain a highly viscous paste, which was slip cast in a cylinder plastic mould and vibrated for $1 \mathrm{~min}$ to remove air bubbles. The specimens were covered for $24 \mathrm{~h}$ with a thin polymer film to maintain a constant level of moisture, then, they were air exposed to complete alkali consolidation at room temperature $\left(25 \pm 3{ }^{\circ} \mathrm{C}\right)$. However, consistency of some samples was not sufficient after a total of $48 \mathrm{~h}$, revealing an uncompleted alkali activation. Therefore, thermal treatments were performed on one sample of volcanic ash (VLA1) and four samples of ghiara (GHI1-4), as listed in the Table 1. The difference in terms of samples tested of each volcanic material for the aforementioned thermal treatments was due to the numerous results reported in literature for thermal treatment of AAMs based on volcanic ash [24]. On the contrary, no data were available for alkali synthesis of materials similar to the studied ghiara.

We also prepared AAMs with the addition of metakaolin to avoid thermal treatments and thus to reduce environmental impact in terms of energy and emission. In detail, two series were produced: one for each volcanic material (VM1 and GM1) with an increase of metakaolin from 5 to $25 \%$ on total weight of the volcanic powder (called: VM1-5/25\% and GM1-5/25\%), as reported in the Table 1 . Moreover, different $\mathrm{NaOH} / \mathrm{Na}_{2} \mathrm{SiO}_{3} \%$ ratios (using a ratio $\mathrm{SiO}_{2} / \mathrm{Na}_{2} \mathrm{O}=2$ ) were used (Table 1) in order to investigate the best conditions to avoid efflorescence on samples' surface after air exposition.

Regarding the formulations of these groups of AAMs, a methodological approach was considered, structured as following: preparation of the precursors, sieving step of the powders to well homogenise the matrix and avoid the formation of metakaolin clumps, mixing with mechanical mixer with addition of alkaline solution, filling in moulds
Fig. 4 Representative photographs of cubic samples regarding the series GM1 (a) and VM1 (b) after polishing surfaces step, prepared for the mechanical compressive test
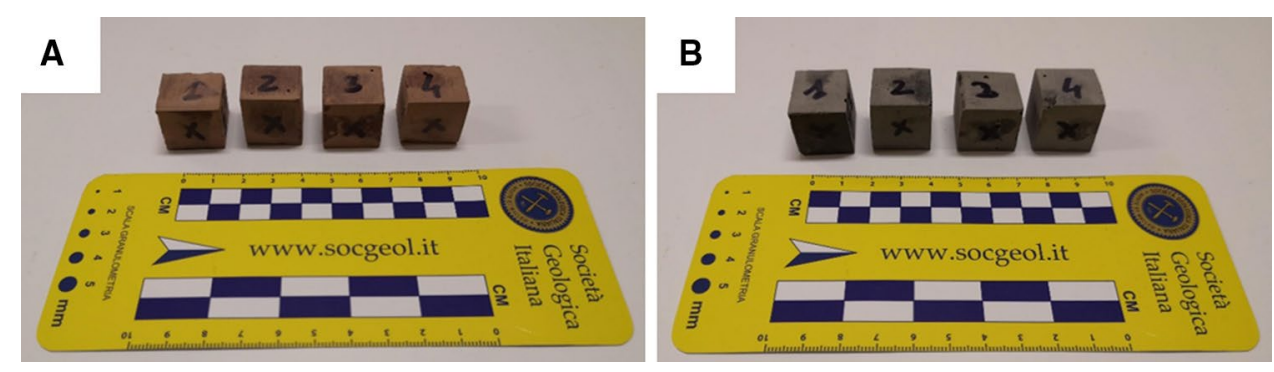
Table 1 Labels, formulation, features and analysis carried out on samples considered in this work (metakaolin percentage was calculated on the basis of the total aluminosilicate powder)

\begin{tabular}{|c|c|c|c|c|c|}
\hline & $\begin{array}{l}\mathrm{NaOH} \\
\text { \%weight }\end{array}$ & $\mathrm{Na}_{2} \mathrm{SiO}_{3} \%$ weight & Water (ml) & $\begin{array}{l}\text { Metakaolin } \\
\% \text { weight }\end{array}$ & Curing temp./time \\
\hline VLA1_100 & 30 & 70 & - & - & $100^{\circ} \mathrm{C}(48 \mathrm{~h})$ \\
\hline VLA1_400 & 30 & 70 & - & - & $400^{\circ} \mathrm{C}(12 \mathrm{~h})$ \\
\hline GHI4_100 & 50 & 50 & - & - & $100{ }^{\circ} \mathrm{C}(48 \mathrm{~h})$ \\
\hline GHI4_400 & 50 & 50 & - & - & $400{ }^{\circ} \mathrm{C}(12 \mathrm{~h})$ \\
\hline GHI1_100 & 23 & 77 & 2 & - & $100^{\circ} \mathrm{C}(24 \mathrm{~h})$ \\
\hline GHI1_400 & 23 & 77 & 2 & - & $400^{\circ} \mathrm{C}(8 \mathrm{~h})$ \\
\hline GHI2_100 & 50 & 50 & 1.5 & - & $100{ }^{\circ} \mathrm{C}(24 \mathrm{~h})$ \\
\hline GHI2_400 & 50 & 50 & 1.5 & - & $400^{\circ} \mathrm{C}(8 \mathrm{~h})$ \\
\hline GHI3_100 & 50 & 50 & - & - & $100{ }^{\circ} \mathrm{C}(24 \mathrm{~h})$ \\
\hline GHI3_400 & 50 & 50 & - & - & $400^{\circ} \mathrm{C}(8 \mathrm{~h})$ \\
\hline VM 1-05 & 23 & 77 & - & 5 & $25^{\circ} \mathrm{C}$ \\
\hline VM 1-10 & 23 & 77 & - & 10 & $25^{\circ} \mathrm{C}$ \\
\hline VM 1-15 & 23 & 77 & - & 15 & $25^{\circ} \mathrm{C}$ \\
\hline VM 1-20 & 23 & 77 & - & 20 & $25^{\circ} \mathrm{C}$ \\
\hline VM 1-25 & 23 & 77 & - & 25 & $25^{\circ} \mathrm{C}$ \\
\hline VM1-20LS & 30 & 70 & - & 20 & $25^{\circ} \mathrm{C}$ \\
\hline VM5-20 & 10 & 90 & 4 & 20 & $25^{\circ} \mathrm{C}$ \\
\hline VMT2-10 & 10 & 90 & - & 10 & $25^{\circ} \mathrm{C}$ \\
\hline VMT1-20 & 40 & 60 & - & 20 & $25^{\circ} \mathrm{C}$ \\
\hline VMT3-15 & 40 & 60 & - & 15 & $25^{\circ} \mathrm{C}$ \\
\hline VMX-20 & 50 & 50 & - & 20 & $25^{\circ} \mathrm{C}$ \\
\hline VMT4-25 & 60 & 40 & - & 25 & $25^{\circ} \mathrm{C}$ \\
\hline VM4-20LS & 60 & 40 & - & 20 & $25^{\circ} \mathrm{C}$ \\
\hline GM 1-05 & 27 & 73 & - & 5 & $25^{\circ} \mathrm{C}$ \\
\hline GM 1-10 & 27 & 73 & - & 10 & $25^{\circ} \mathrm{C}$ \\
\hline GM 1-15 & 27 & 73 & - & 15 & $25^{\circ} \mathrm{C}$ \\
\hline GM 1-20 & 27 & 73 & - & 20 & $25^{\circ} \mathrm{C}$ \\
\hline GM 1-25 & 27 & 73 & - & 25 & $25^{\circ} \mathrm{C}$ \\
\hline GHIT3-15 & 10 & 90 & - & 15 & $25^{\circ} \mathrm{C}$ \\
\hline GM1-20 LS & 30 & 70 & - & 20 & $25^{\circ} \mathrm{C}$ \\
\hline GHIT1-20 & 40 & 60 & - & 20 & $25^{\circ} \mathrm{C}$ \\
\hline GHI5-20 & 50 & 50 & - & 20 & $25^{\circ} \mathrm{C}$ \\
\hline GHIT2-20 & 60 & 40 & - & 20 & $25^{\circ} \mathrm{C}$ \\
\hline
\end{tabular}

The letter V indicates volcanic ash; G: ghiara; and M: metakaolin

The horizontal straight line divides up the samples with $\mathrm{Na}_{2} \mathrm{SiO}_{3}$ provided by Carlo Erba company above, from those below by Ingessil s.r.l and vibration to remove micro air bubbles; covering with plastic films for $24 \mathrm{~h}$ to maintain $100 \%$ humidity and following exposition to air; removal of specimens once obtained consolidation after $24 / 36 \mathrm{~h}$ from the moulds; rectification surfaces (Fig. 5).

\section{Results}

Formulations (Table 1) were performed taking into account chemical compositions of both volcanic ash and ghiara powders carried out with XRF. The averages of the major elements' chemical analysis are listed in in Table 2 in weight percentage. Moreover, considering the importance of the amorphous content (volcanic glass) of the precursors for the alkaline activation, we reported in Table 2 its chemical composition by literature [6].

Chemical compositions (Table 2) of both raw materials are quite similar, but ghiara has a higher $\mathrm{Al}_{2} \mathrm{O}_{3}$ abundance and on average lower $\mathrm{CaO}$ than volcanic ashes. Moreover, mineralogical compositions (Figs. 6, 7) of these materials were estimated by means of XRD analysis, using quantitative Rietveld methods (Table 3 including indications of the crystallographic cards used for refinement processing). In 


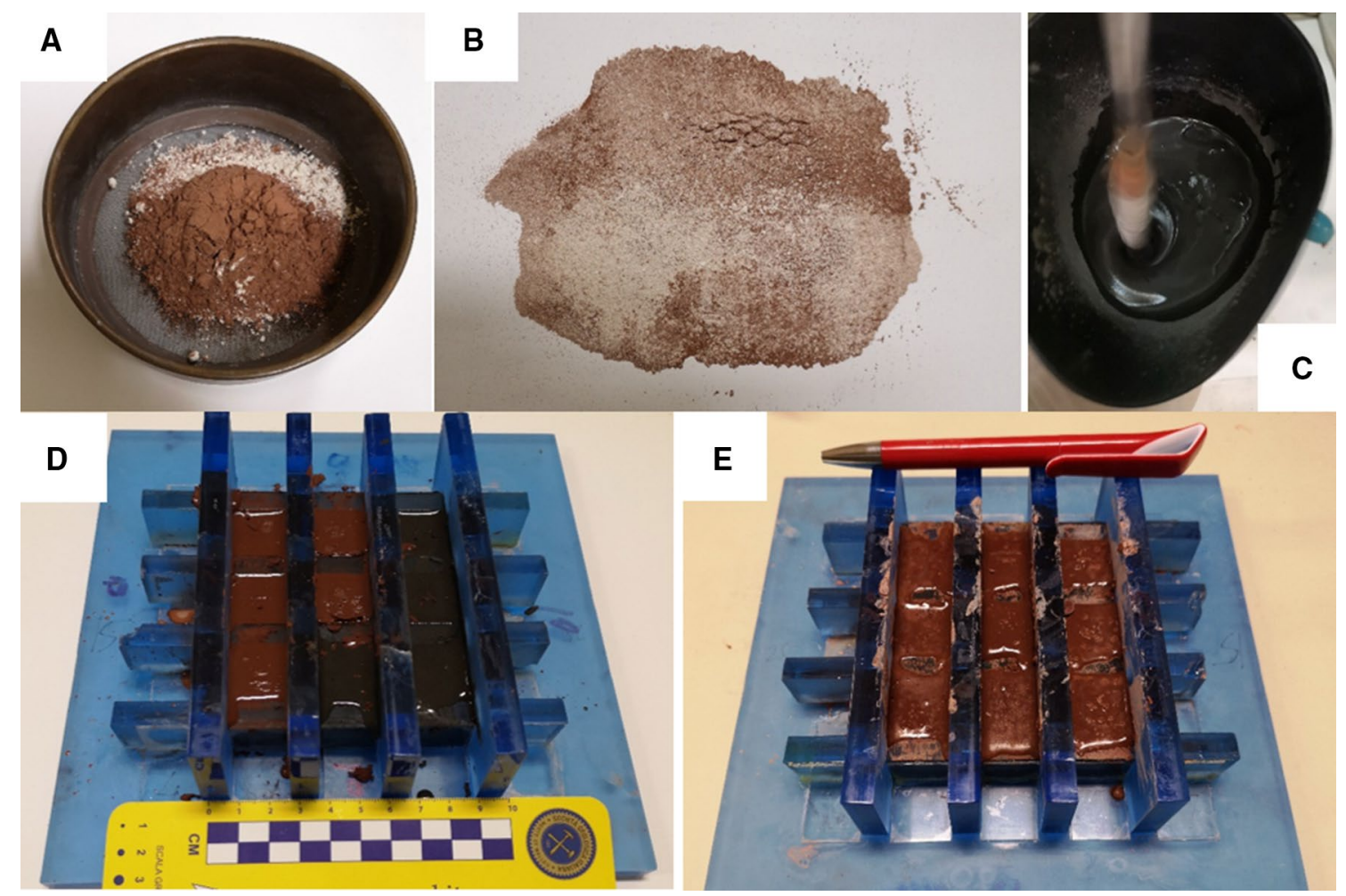

Fig. 5 Summary of the main steps for AAMs production with MK addition. a mixing of ghiara and metakaolin and use of a sieve to homogenise; b result after the sieving step; c mixing with alkaline solution and mechanical mixer; $\mathbf{d}$ fill of cubic moulds with the fresh slurry; e after $24 / 36 \mathrm{~h}$ of consolidation and before to unmould
Table 2 Major elements of studied raw materials (XRF) and of volcanic glass (SEMEDS)

\begin{tabular}{|c|c|c|c|c|c|c|}
\hline & \multicolumn{2}{|c|}{ Volcanic ash } & \multicolumn{2}{|l|}{ Ghiara } & \multicolumn{2}{|c|}{ Volcanic glass } \\
\hline & Average & $\mathrm{SD}$ & Average & $\mathrm{SD}$ & Average & SD \\
\hline $\mathrm{SiO}_{2}$ & 49.1 & 0.4 & 50.0 & 1.4 & 50.3 & 0.8 \\
\hline $\mathrm{TiO}_{2}$ & 2.0 & 0.1 & 1.5 & 0.1 & 2.3 & 0.0 \\
\hline $\mathrm{Al}_{2} \mathrm{O}_{3}$ & 16.4 & 1.0 & 19.5 & 1.1 & 15.7 & 0.3 \\
\hline $\mathrm{Fe}_{2} \mathrm{O}_{3}$ & 11.7 & 0.8 & 11.6 & 0.5 & 10.6 & 0.1 \\
\hline $\mathrm{MnO}$ & 0.2 & 0.0 & 0.2 & 0.0 & 0.2 & 0.0 \\
\hline $\mathrm{MgO}$ & 4.0 & 0.4 & 2.8 & 0.4 & 2.9 & 0.2 \\
\hline $\mathrm{CaO}$ & 10.5 & 0.4 & 7.8 & 0.9 & 7.5 & 0.4 \\
\hline $\mathrm{Na}_{2} \mathrm{O}$ & 3.5 & 0.2 & 3.5 & 0.7 & 4.2 & 0.2 \\
\hline $\mathrm{K}_{2} \mathrm{O}$ & 2.0 & 0.1 & 1.7 & 0.2 & 4.0 & 0.3 \\
\hline $\mathrm{P}_{2} \mathrm{O}_{5}$ & 0.4 & 0.1 & 0.6 & 0.2 & - & - \\
\hline LOI & 0.4 & 0.2 & 0.9 & 0.6 & - & - \\
\hline $\mathrm{SiO}_{2} / \mathrm{Al}_{2} \mathrm{O}_{3}$ (molar ratio) & 5.1 & 0.3 & 4.4 & 0.3 & 5.4 & 0.1 \\
\hline $\mathrm{SiO}_{2}+\mathrm{Al}_{2} \mathrm{O}_{3}$ & 65.4 & 0.6 & 69.4 & 1.7 & 65.9 & 1.0 \\
\hline
\end{tabular}

The abundances are expressed as weight $\%$ of oxides

general, they showed more than $50 \%$ of amorphous phase (volcanic glass), in the particular case of volcanic ash, the value reached almost $75 \%$, so perfectly compatible to be used in alkali synthesis. Additionally, volcanic ash evidenced the typical mineralogical phases of Mt. Etna basaltic rocks, such as calcium plagioclase, pyroxene and olivine $[6$,
34] while ghiara paleo-soil highlighted, in addition to the aforementioned phases, iron oxides and hydroxides (goethite and hematite) and, in some cases, calcite. 


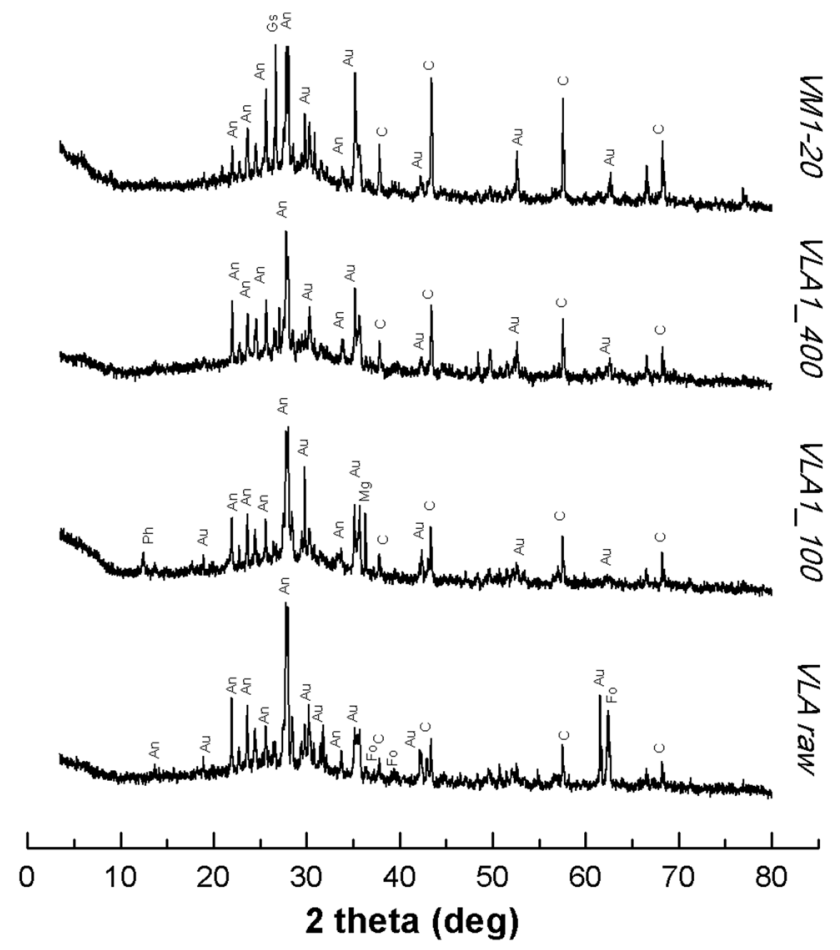

Fig. 6 Representative pattern of volcanic ash for following typology: raw material, treated at $100 / 400{ }^{\circ} \mathrm{C}$ and one with metakaolin addition (20\%) (An: anorthite; Au: Augite; Fo: forsterite; $\mathrm{Mg}$ : maghemite; $\mathrm{Ph}$ : phillipsite; Gs: gismondine; C: corundum)

\section{Volcanic Ash AAMs: Integrity Test}

Results regarding the integrity test of AAMs based on volcanic ash only failed to dissolve partially or completely. Therefore, thermal treatments were performed on these formulations to reach densification and to complete alkali consolidation process. Indeed, thermal treatments represent an important synthesis parameter for low reactivity materials, such as volcanic ones [24, 35-37]. Moreover, their effects were directly correlated to the mechanical behaviour [24]. In detail, VLA1 sample treated at $400{ }^{\circ} \mathrm{C}$ was chemically stable, while the sample at $100{ }^{\circ} \mathrm{C}$ did not pass the integrity test.

More interesting are the results of AAMs based on volcanic ash also when added of 5-25 wt $\%$ of metakaolin. In this case (VM1 set), the use of activation solution (formed by $\mathrm{NaOH}=23 \%$ and pure water glass $=77 \%$ ) produced AAMs with good chemical and resistance features with the exception of the sample with 5\% of metakaolin. A second parameter to keep in consideration to establish the quality of the geopolymers is the appearance of the white efflorescence consisting of trona $\left(\mathrm{Na}_{3}\left(\mathrm{CO}_{3}\right) \cdot\left(\mathrm{HCO}_{3}\right) \cdot 2\left(\mathrm{H}_{2} \mathrm{O}\right)\right)$, as determined by XRD analysis. In VM1 set, efflorescence occurrence was observed on samples with metakaolin content lower than of $20 \%$.

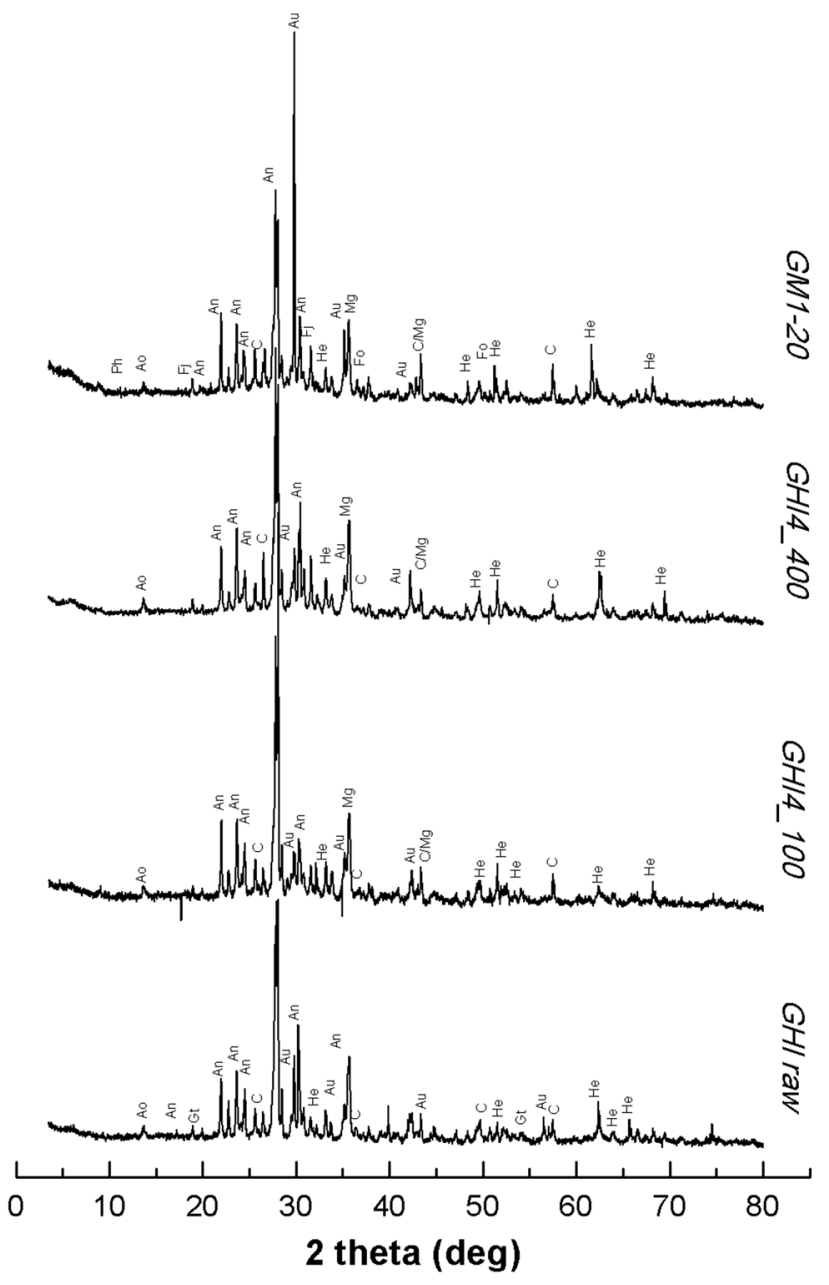

Fig. 7 Representative pattern of ghiara for following typology: raw material, treated at $100 / 400{ }^{\circ} \mathrm{C}$ and one with metakaolin addition (20\%) (An: anorthite; Ao: anortoclase; Au: augite; Fo: forsterite; He: hematite; Gt: gohetite: $\mathrm{Mg}$ : maghemite; $\mathrm{Ph}$ : phillipsite; Fj: faujasite; C: corundum)

With the aim to investigate the formulations that do not have this undesirable behaviour, other AAMs with different activators ratio and metakaolin content were produced and passed the integrity test (VM5-20; VMT2-10; VM1-20 LS; VMT1-20; VMT3-15; VMX-20; VMT4-25; VM4-20 LS, see Table 1). Among these, VM1-20 LS was produced also with the aim to reduce the addition of sodium silicate, to reach high viscosity and to maintain a low setting time.

\section{Ghiara AAMs: Integrity Test}

At the same time, integrity test results of AAMs based on ghiara only, showed negative effects in terms of the chemical stability test and mechanical resistance suggesting an incomplete consolidation. For this reason, samples underwent thermal treatments to reach consistency and hardness. In this 
Table 3 Mineralogical results obtained by XRD analysis with Rietveld Method

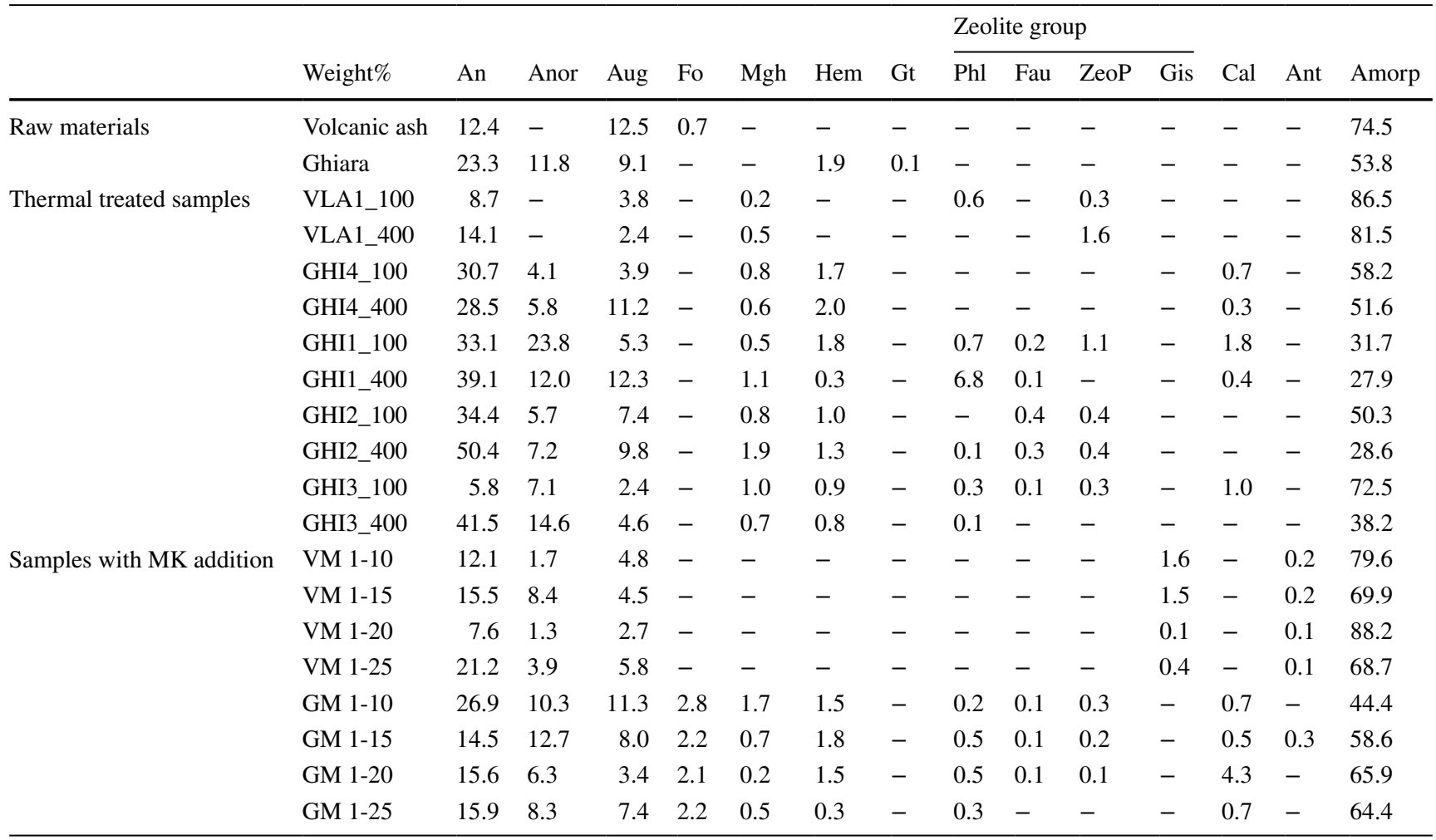

An: Anorthite, amcsd 0001287 [42]; Anor: Anorthoclase, code 9000855 [43]; Aug: Augite, code 1000035 [44]; Fo: Forsterite, amcsd 0000886 [45]; Mgh: Maghemite, amcsd 0013508 [46]; Hem: Hematite, amcsd 0002228 [47]; Gt: Goethite, amcsd 0002226 [47]; Phl: Phillipsite, amcsd 0012860 [48]; Fau: Faujasite, amcsd 0006772 [49]; ZeoP: Zeolite P, 8104214 [50]; Gis: Gismondine, amcsd 0020103 [51]; Cal: Calcite, amcsd 0000989 [52]; Ant: Anatase, amcsd 0011765 [53]; Amorp: Amorphous

case, since the use of ghiara have not been studied up to now for AAM production, two formulations (GHI1 and GHI4) with different $\mathrm{NaOH}$ percentage were investigated. Furthermore, three samples for each formulation were analysed with the aim to have statistically representative data. All samples already reached a good stability and stiffness at $100{ }^{\circ} \mathrm{C}$ (after $48 \mathrm{~h}$ ), even though, impurities observed in water suggest a not complete activation. This demonstrates the efficiency of thermal treatment in enhancing the reactivity of the precursors powder and the potentiality of alkali activation of volcanic residues, even if the treatment at $100-400{ }^{\circ} \mathrm{C}$ is not a realistic solution to be used in-situ applications.

Using the same approach described for the volcanic ash formulations, AAMs based on ghiara and metakaolin were produced to obtain a complete scenario on efflorescence occurrence. A "green" formulation containing lower amount of Na-silicate (GM1-20 LS) with ghiara precursor was also produced and it demonstrates good water resistance.

\section{XRD Results of AAMs}

The used raw materials and the produced AAMs showed, as attested in the literature [18, 38-40], high amorphous content as evidenced by the broad band in the 20-35 $2 \Theta$ range. The mineralogical phases typical of Mt. Etna volcanic ash (i.e. Ca-rich plagioclase, pyroxene, and olivine) and ghiara (i.e. Ca-rich plagioclase, anorthoclase, pyroxene, hematite, goethite \pm calcite) are the prevalent ones in the raw materials as well as in AAMs. In these latter, in many cases, zeolites (phillipsite, zeolite-P, faujasite) are present, suggesting the formation of novel and more ordered structure during the polymeralization process [41]. Finally, anatase is present in little quantity in the samples containing $\mathrm{MK}$ as accessory phase in kaolinitic materials (Table 3).

In particular, regarding the volcanic ash AAMs, the qualitative and quantitative analysis gives the following results: (i) in AAMs thermally treated and based on volcanic ash only (VLA1), the amorphous phase is the more abundant (> 80\%) both after $100{ }^{\circ} \mathrm{C}$ and $400{ }^{\circ} \mathrm{C}$ curing; (ii) in the $100{ }^{\circ} \mathrm{C}$ sample, zeolite $\mathrm{P}$ and phillipsite are present, while in the $400{ }^{\circ} \mathrm{C}$ only zeolite $\mathrm{P}$ is observable; (iii) in the samples obtained with the addition of MK (VM1), gismondina is the zeolitic phase observed (Fig. 6) (Table 3). The presence of zeolites after thermal treatment can be related to the reorganization of geopolymeric gel formed after alkali activation induced by temperature. In addition, XRD analysis 
performed on samples exposed to air, evidenced trona and thermonatrite as carbonatic phases occurred during consolidation due to the reactivity of excess $\mathrm{Na}+$ with $\mathrm{CO}_{2}$. These phases are not present in the bulk samples but only on the surface layer in contact with atmosphere.

On the other hand, mineralogical results related to AAMs based on ghiara evidenced: (i) in thermally treated AAMs, on average, we found a lower amorphous phase abundance than in the corresponding volcanic ash AAMs; (ii) the amorphous percentage of the formulations treated at $400{ }^{\circ} \mathrm{C}$ is lower than those treated at $100{ }^{\circ} \mathrm{C}$; (iii) in all the thermally treated samples, small amount of zeolite were observed; (iii) GM1 set showed amorphous content higher than $44 \%$ and phases belonging to zeolite group in small quantities (Fig. 7).

\section{Water Absorption and Porosity of AAMs}

According to total absorption test results, the analysed samples reached the saturation very rapidly. Indeed, the water absorption range between 9 and $15 \%$ for both volcanic precursors (Table 4). Moreover, the samples with only $10 \mathrm{wt} \%$ of metakaolin evidenced the lowest percentage. However, we assumed that efflorescence formation influenced these results.

$\mathrm{Hg}$ porosimetry data showed a microporosity with an average accessible porosity of $27.31 \%$ and average pore diameter of $0.08 \mu \mathrm{m}$ for VM1 series while $26.06 \%$ and $0.05 \mu \mathrm{m}$ for GM1 one (Table 5). Considering the amount of metakaolin added and the difference of alkaline solution in the "green" formulations, both series evidenced same features: the samples with $20 \mathrm{wt} \%$ of MK showed a higher volume in the pore sizes range $0.1-0.01 \mu \mathrm{m}$ than those with $10 \mathrm{wt} \%$, while the samples with lower liquid/solid ratio (LS composition) evidenced a similar pore volume distribution but a lower accessible porosity. All samples of both series were compared with the corresponding samples aged after 1 year (Fig. 8a, b). The average value of this latter highlighted a decrease of accessible porosity and an increase of pore volume in the range $0.1-0.01 \mu \mathrm{m}$ while the pores in the range $100-1 \mu \mathrm{m}$ decrease with the exception of GM1-10 samples.

Table 4 Results of permeable porosity test for total absorption (Wa) and average density of cubes prepared for mechanical compressive test

\begin{tabular}{lll}
\hline Samples & $\rho\left(\mathrm{g} / \mathrm{cm}^{3}\right)$ & $\mathrm{W}_{\mathrm{a}} \%$ \\
\hline VM1-10 & 1.94 & 9 \\
VM1-20 & 1.84 & 12 \\
VM1-20 LS & 1.99 & 15 \\
GM1-10 & 2.03 & 9 \\
GM1-20 & 1.89 & 14 \\
GM1-20 LS & 1.96 & 15 \\
\hline
\end{tabular}

\section{pH and lonic Solution Conductivity Measurements of AAMs}

The ionic conductivity is electrical conductivity due to the motion of all the free ionic charges presented in the solution and it is linked directly to the total dissolved solids. The results of $\mathrm{pH}$ and ionic solution conductivity measurements of AAMs based on volcanic ash and ghiara belonging to the VM1 and GM1 series with 10-25\% of metakaolin showed interesting information about chemical stability. Both $\mathrm{pH}$ and ionic conductivity measures are related to the ions released in water by the solid geopolymer. Concerning $\mathrm{pH}$ values, they remain fairly constant during the $24 \mathrm{~h}$ of test for both the VM1 and GM1 series, confirming the chemical stability of the material showing a steady value already after $15 \mathrm{~min}$ and an average value slightly below 10 .

As regards the conductivity results, it can be noted that the conductivity increases with the time (Fig. 9a, c), due to a release of ions into the water, with a similar trend for VM1 and GM1 series.

It is interesting to note that with the increase of the percentage of metakaolin in the compositions, conductivity values decrease as the consequence of greater chemical stability of the formulation due to the composition optimization induced by metakaolin, which favors a higher degree of geopolymerization (Fig. 9b, d). The values of ionic conductivity are just one order of magnitude higher than that typical drinking water in the range of $5-50 \mathrm{mS} / \mathrm{m}$. Other values that can be used as reference are high quality deionized water has a conductivity of about $5.5 \mu \mathrm{S} / \mathrm{m}$ at $25{ }^{\circ} \mathrm{C}$, while sea water around $5 \mathrm{~S} / \mathrm{m}$ (or $5,000,000 \mu \mathrm{S} / \mathrm{m}$ ). From the graphs (Fig. 9a-d) of conductivity it appears evident that the effect of metakaolin is stronger in composition based on ghiara with respect to volcanic ash and the decrease of conductivity is particular evident for longer immersion times. Furthermore, the proper dosage of alkaline solution (samples named LS) leads to a decrease of conductivity, with respect to samples containing the same amount of metakaolin. This behaviour confirms the higher stability of the matrix formulated.

\section{Microstructural Analysis of AAMs}

All the SEM images obtained at low magnifications showed a microporous structure typical of these materials [20, 26, 54-56] with variable pore size in the range of 50-200 $\mu \mathrm{m}$ and rounded shape (Fig. S1 as supplementary file). These pores occurred during sample preparation as air entrapped during mixing was not able to get to the surface as a consequence of paste's high viscosity. The grains of volcanic ash appeared as irregular polyhedral particles with dimensions measured in the $20-100 \mu \mathrm{m}$ range as well as reported by [20]. 


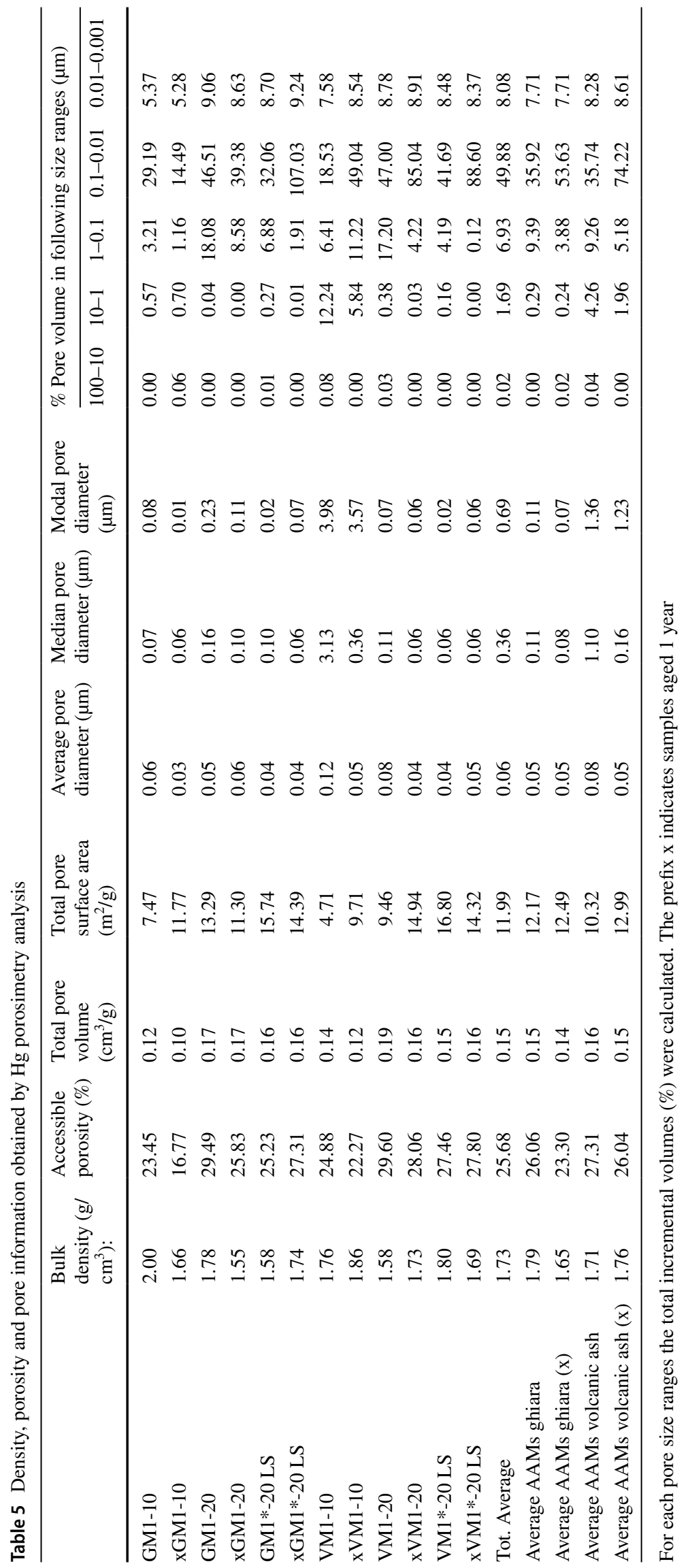



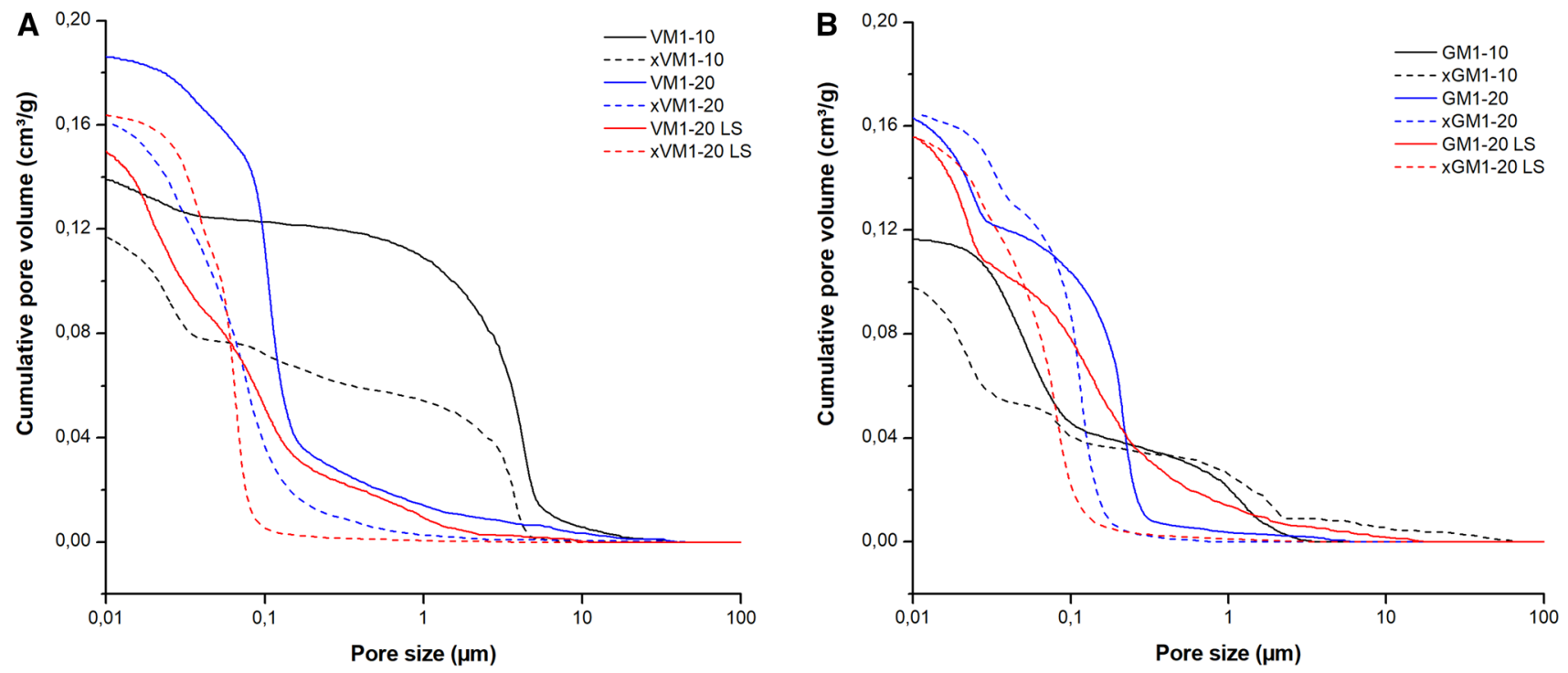

Fig. 8 Cumulative pore volume vs pore size graphs: a representative samples of VM1 set and the corresponding aged 1 year (dashed lines); b representative samples of GM1 set and the corresponding aged 1 year (dashed lines)
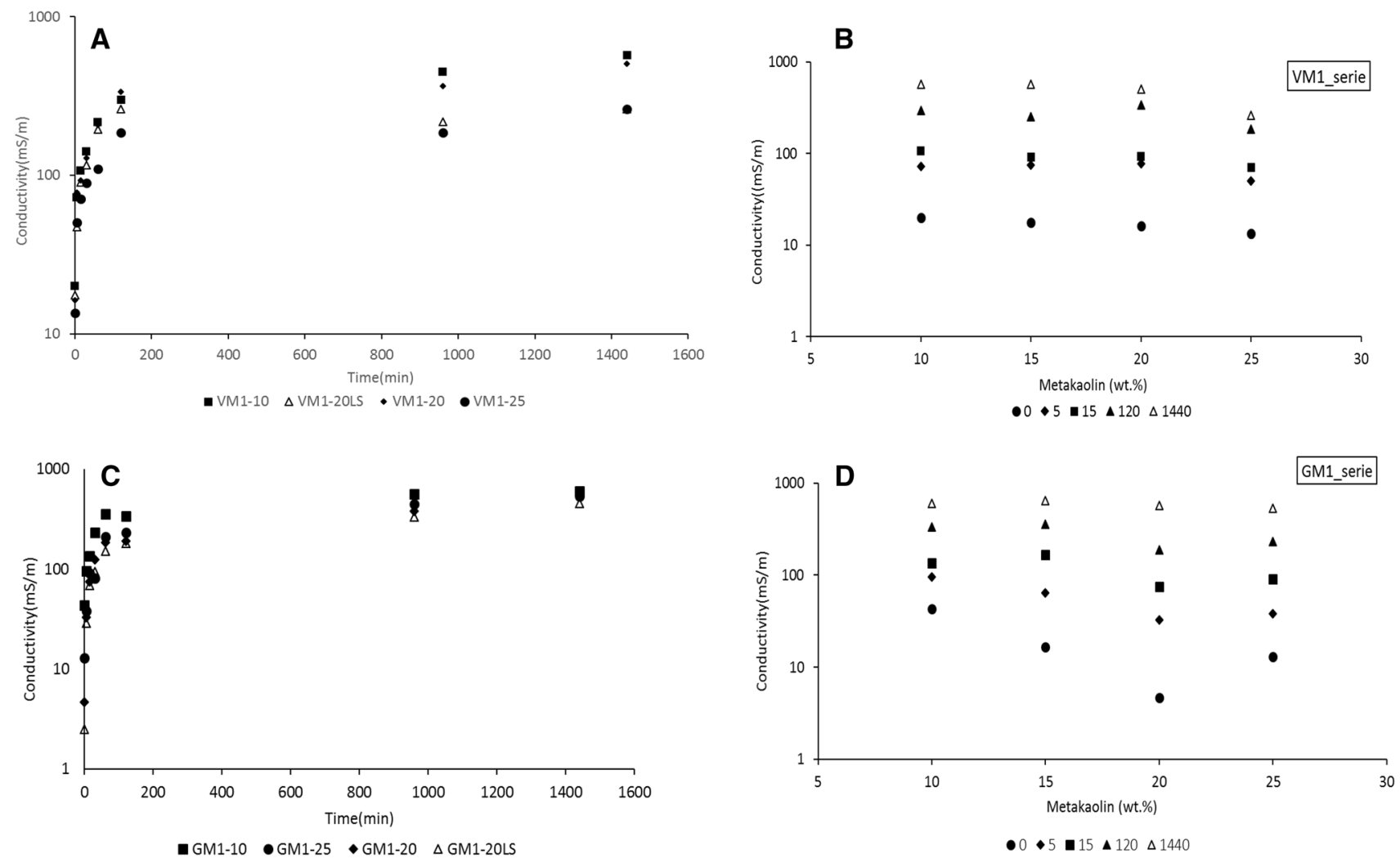

Fig. 9 Conductivity values for prepared formulations containing volcanic ash and ghiara as a function of metakaolin content (b, d) and time (a, c) (instrument sensibility \pm 0.01 )

Contemporary, other images were taken at high magnifications to evidence the finer microstructure and to collect the local chemical compositions in different spot analysis (Fig. 10a-d). Generally, the AAMs evidenced: 


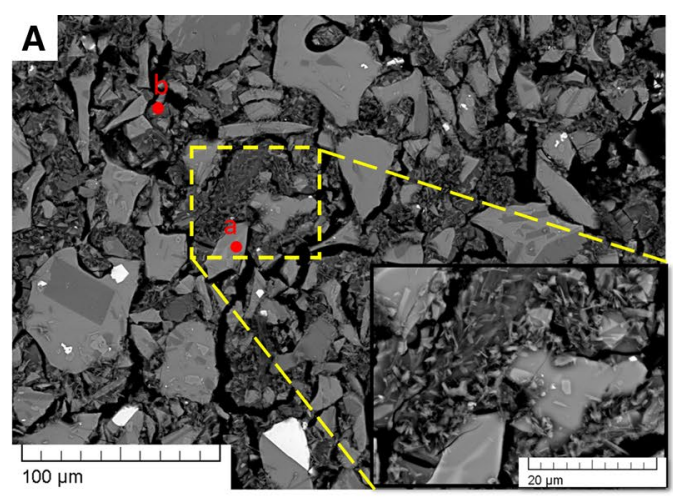
a)

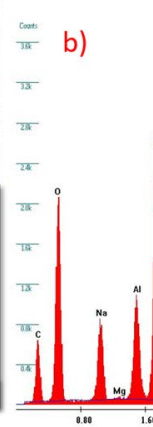

उत्

"4

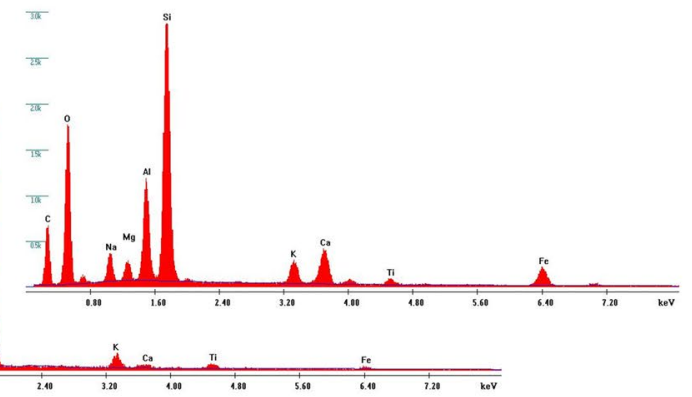

B
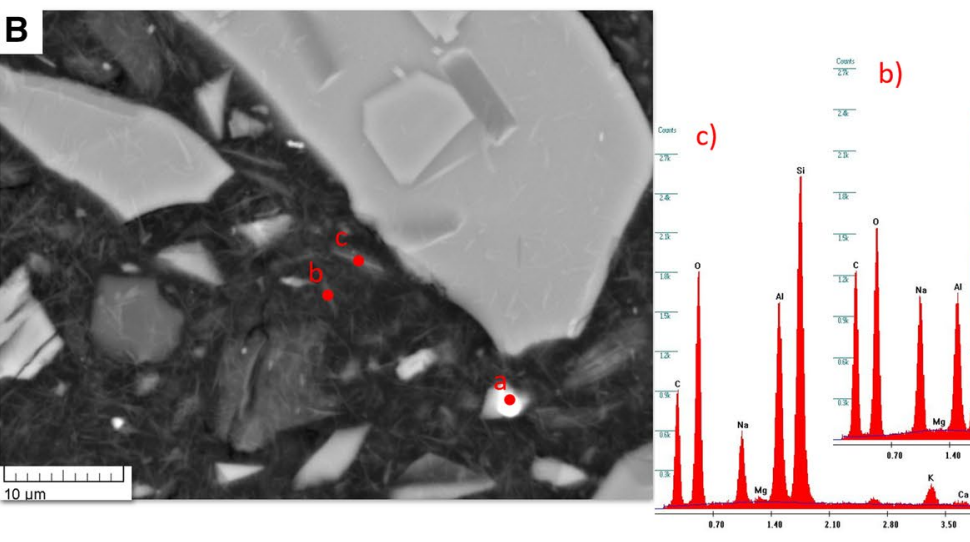

a)
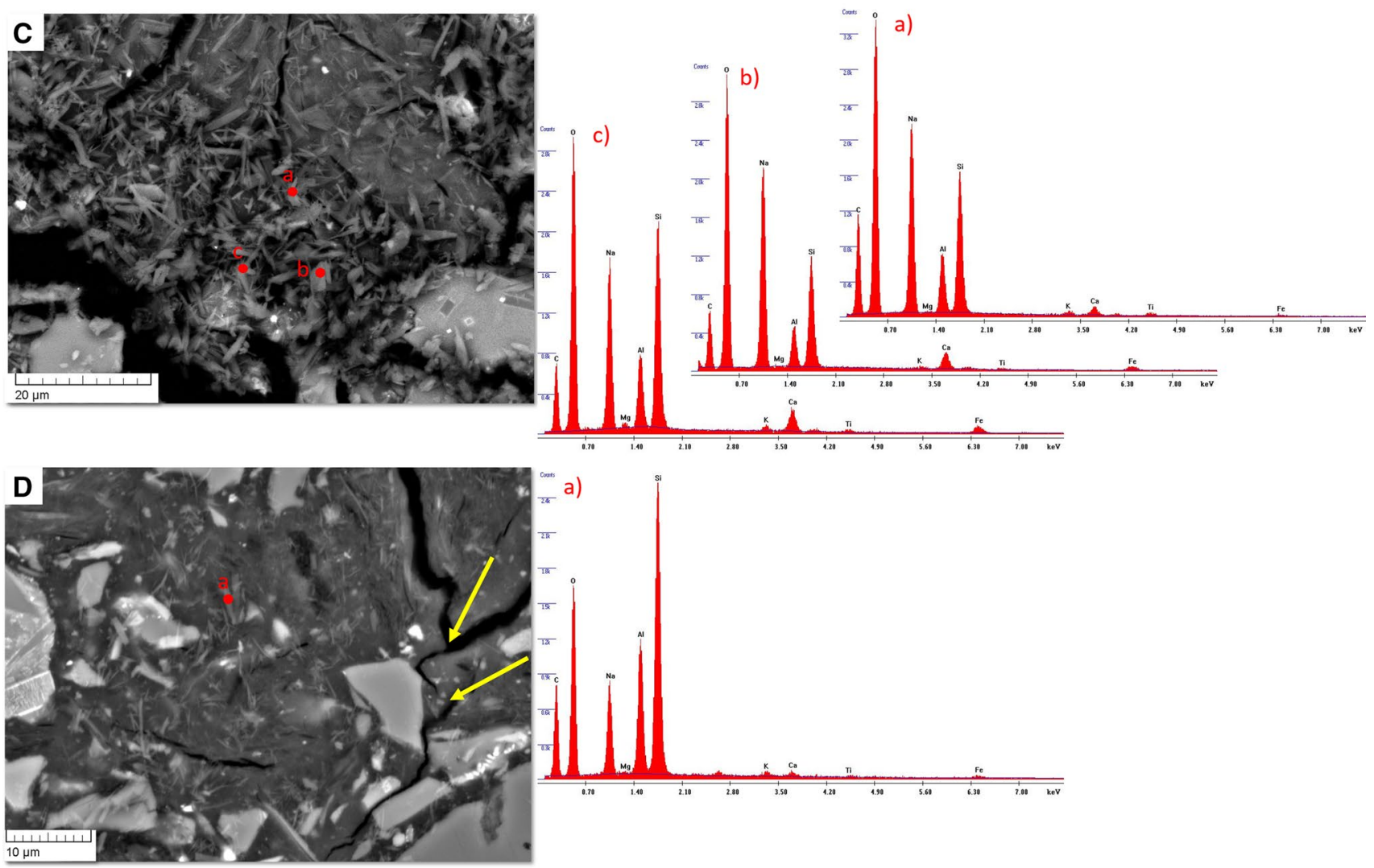
4Fig. 10 SEM micro-images of thin sections with high magnifications with spot analysis expressed in red dots, EDS spectra of representative point analyses and tables with histograms where weight of the oxides (wt\%) are listed. Legenda: a sample VM1-10 (magnifications $\times 498$ and $2.38 \mathrm{kx}$ ); b sample VM1-20 (magnification $3.67 \mathrm{kx}$ ); c sample GM1-10 (magnification $2.58 \mathrm{kx}$ ); d sample GM1-20 (magnification $3.23 \mathrm{kx}$ ). Crack deflection mechanism indicated by yellow arrows. (Color figure online)

- A major micro porosity (pore diameter range 50-200 $\mu \mathrm{m}$ ) was detected on samples with $10 \mathrm{wt} \%$ of metakaolin (VM1-10 and GM1-10) in comparison with the others (VM1-20 and GM1-20; see supplementary files).

- All samples at high magnifications showed elongated and acicular crystals whose compositions appeared to be similar to that of the sodium carbonate laid down onto the amorphous matrix of geopolymeric gel [57] (for example point "b" in Fig. 10a).

- Other grains were detected with affinities in chemical compositions to volcanic glass (point "a" in Fig. 10a), or relict mineralogical phases not completely reacted during alkali activation (e.g. point "a" in Fig. 10b).

- Plies of metakaolin foils are not evidenced, indicating a good mixing process during fresh paste preparation.

Cracks and void are difficult to analyse and discuss due to fracturing operation during sample preparation. Nevertheless, the presence of irregular polyhedral grains of volcanic ash act as reinforcement for the alkali activated matrix, with crack bending or crack deflection toughening mechanism as indicated by the arrows in Fig. 10d.

\section{Mechanical Compressive Strength of AAMs}

The AAMs samples showed density ranging $1.7-2 \mathrm{~g} / \mathrm{cm}^{3}$ calculated after $24 / 36 \mathrm{~h}$ and the rectification step. Regarding the series VM1 and GM1 and their "green" formulations, the mechanical compressive values range from 10 to $38 \mathrm{MPa}$ after 28 days of curing (Table 6). The values of both series showed higher mechanical strengths with increasing of metakaolin content (wt\%) (Fig. 11). This behaviour is more evident in GM1 set than in VM1 set. However, the results of green formulations of both series, where precursors and activators were mixed in the same ratios, confirmed the chemical similarity of these volcanic precursors.

\section{Discussion}

According to the chemical and mineralogical compositions, both the studied volcanic residues represent suitable aluminosilicate precursors for AAMs production thanks to their high volcanic glass abundances and the $\mathrm{Si} / \mathrm{Al}$ ratios of the bulk and of the amorphous phase [38]. Furthermore,
Table 6 Summary table with the average values regarding the density after 24/36 h and mechanical strength after 28 curing days with its relative standard deviation $(\mathrm{SD})$

\begin{tabular}{llll}
\hline Labels & \multicolumn{2}{l}{ After 28 curing days } \\
\cline { 2 - 4 } & AAMs $\rho\left(\mathrm{g} / \mathrm{cm}^{3}\right)$ & $\sigma(\mathrm{MPa})$ & $\mathrm{SD}( \pm)$ \\
\hline VM1-10 & 1.9 & 14.3 & 2.6 \\
VM1-15 & 1.9 & 15.3 & 1.1 \\
VM1-20 & 1.8 & 20.5 & 4.8 \\
VM1-25 & 1.8 & 38.0 & 1.1 \\
VM1-20 LS & 2.0 & 32.0 & 4.7 \\
GM1-10 & 2.0 & 10.8 & 0.7 \\
GM1-15 & 2.0 & 20.7 & 4.4 \\
GM1-20 & 1.9 & 25.3 & 2.0 \\
GM1-25 & 1.9 & 37.9 & 2.3 \\
GM1-20 LS & 2.0 & 32.2 & 3.2 \\
\hline
\end{tabular}

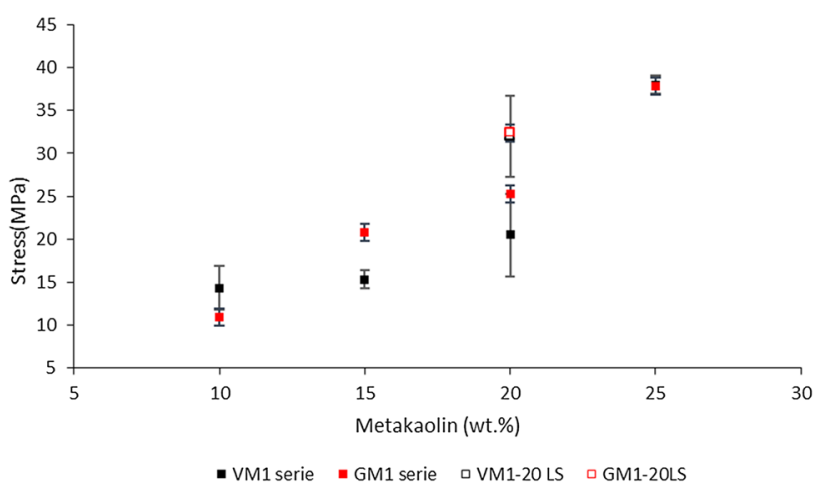

Fig. 11 Correlation between compressive strengths and metakaolin (wt\%)

chemical and mineralogical composition of Mt. Etna lavas are similar to other volcanic rocks used in literature for geopolymer productions [20,25]. However, the exclusive use of Mt. Etna raw materials with grain size round $<75 \mu \mathrm{m}$, without the addition of low percentages of metakaolin, at room temperature evidenced negative results since such formulations do not pass the integrity test. The thermal curing at 100 and $400{ }^{\circ} \mathrm{C}$ give good results in the formation of AAMs as in the case of fly ash precursors [58] that have similar composition and behaviour of volcanic glass in presence of alkaline solution. In particular, $100{ }^{\circ} \mathrm{C}$ treatment is sufficient to complete the alkaline activation and also to obtain a stiff and solid AAM of ghiara samples while for volcanic ash it is necessary to reach $400{ }^{\circ} \mathrm{C}$. The curing temperatures of 100 and $400{ }^{\circ} \mathrm{C}$ were chosen in order to evaluate the reactivity of volcanic residues as a function of temperature. Obviously, these curing conditions are not suitable for an in-situ application but the results of these tests are instrumental to providing the best possible understanding of the 
alkali activation conditions. In this paper authors decided to modify composition introducing percentage of metakaolin to avoid curing condition at high $\mathrm{T}$.

The difficulty in obtaining good AAMs with Mt. Etna precursors at room temperature may be due to the chemical composition of the reactive amorphous phases and, in particular, the low abundances of $\mathrm{Al}_{2} \mathrm{O}_{3}$ and/or $\mathrm{CaO}$ accompanied with the low reactivity of the volcanic glass. The experimental results demonstrate that the addition of moderate quantities of metakaolin (>10\%) allowed the formation at room temperature of AAMs with good resistance to the integrity test as suggested also by [37]. The formation of geopolymer gel is evidenced by the high amorphous contents highlighted by XRD Rietveld analysis. In addition, in AAMs of both raw materials, the small quantities of minerals belonging to zeolite group confirmed a structural modification after alkaline synthesis [59].

In this context, the presence of white efflorescence consisting of trona and thermonatrite represented an undesirable salification process. With the aim to observe the mixtures that give good results in terms of chemical stability and efflorescence, the data of the experimented geopolymers are reported in Figs. 11 and 12. In particular, samples with the use of volcanic ash, $20 \%$ of metakaolin and $\mathrm{NaOH}$ amount lower than 20\% (VM5-20) or higher than $60 \%$ (VM4-LS) failed the integrity test while the efflorescence is not present in AAMs with $\mathrm{MK}>20 \%$ and $\mathrm{NaOH}<50 \%$.

AAMs with ghiara and the addition of metakaolin content higher than $20 \%$ combined with $\mathrm{NaOH}$ lower than $10 \%$ successfully passed the test, and efflorescence occurrence was not evidenced, such as sample with $\mathrm{NaOH}=20 \%$ and treated

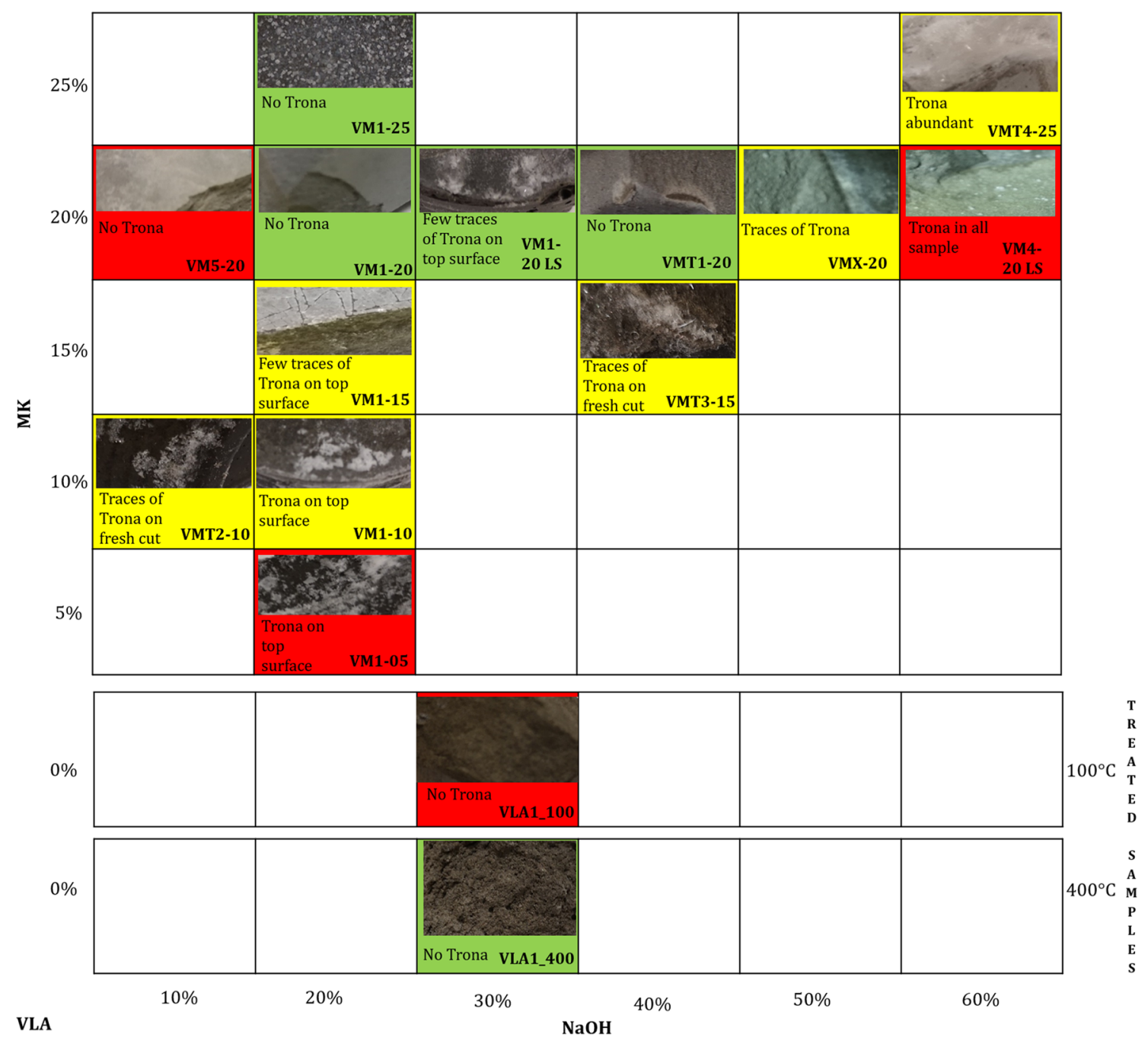

Fig. 12 Carbonates crystallization micro-pictures (approximately each photo represents $1 \mathrm{~cm}^{2}$ of sample) with a short description of AAMs based on volcanic ash and metakaolin with different percentage of $\mathrm{NaOH}$ and metakaolin. Map results evidenced by different col- ours (green: positive and without carbonates crystallization; yellow: passed the integrity test but crystallization occurred; red failed test). (Color figure online) 
at $400{ }^{\circ} \mathrm{C}$ (Fig. 12). Instead, despite the other treated samples and those with $10-15 \%$ of metakaolin and $20 \% \mathrm{NaOH}$ have passed integrity test, carbonates crystallization occurred.

Moreover, the results obtained by efflorescence observations (Figs. 12, 13) showed interesting features: for both raw materials no evidence occurred with $\mathrm{MK}>20 \%$ and $20 \%<\mathrm{NaOH}<50 \%$. Moreover, for AAMs based on ghiara, no Na-carbonates hydrate evidence with $\mathrm{MK}=15 \%$ and $10 \%<\mathrm{NaOH}<20 \%$ occurred, indicating higher durability. This undesirable salification process is linked to an excess of $\mathrm{Na}^{+}$quantity (due to activators) within the pore network, which reacted, after a few days, with air of laboratory atmosphere [60, 61]. Microstructure results showed a good mixing, confirmed by total absence of plies of metakaolin foils, despite the evidence of volcanic glass and mineralogical relicts. Results regarding Hg porosimetry confirmed the micro porosity nature of these materials, highlighting a clear decreasing of pore size vs time, as well as reported by [28]. Indeed, the samples aged one year showed a cumulative pore volume higher in pore size range $0.1-0.01 \mu \mathrm{m}$ contrary to the range $100-1 \mu \mathrm{m}$, than the younger ones. Generally, Ordinary Portland Cement (OPC) concrete has lower water absorption than geopolymer pastes, such as to define OPC in high permeable concrete $(>5 \%)$ and low permeable concrete $(<3 \%)$ [28]. However, considering the possibility to improve the microstructure of geopolymer concrete with the addition of graphene nanoplatelets (GNPs) to geopolymer binders [27] and inversional proportionality between the water absorption and density of geopolymer paste, the obtained values match with those ones found by [62], even though efflorescence phenomena could have influenced them.

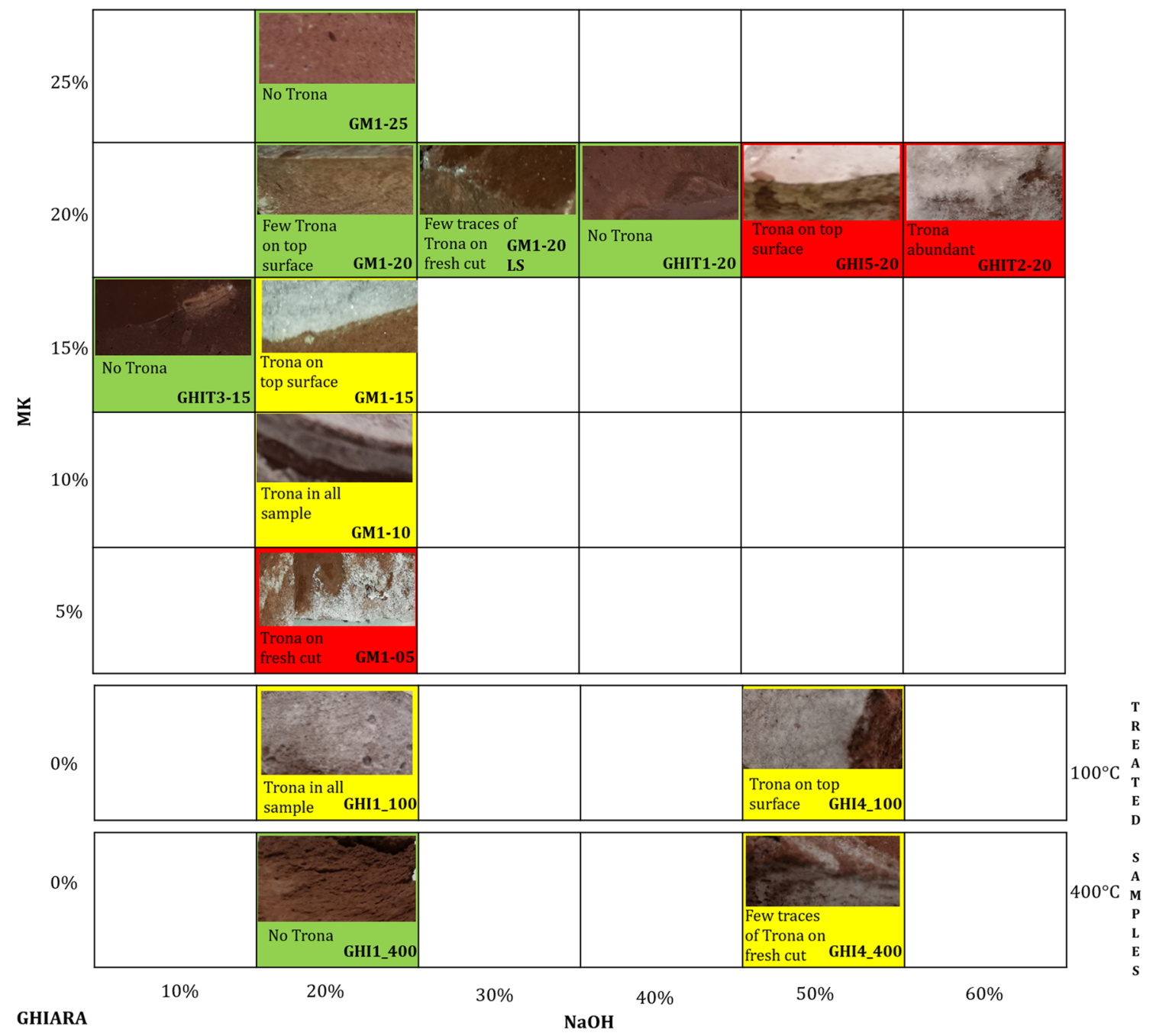

Fig. 13 Carbonates crystallization micro-pictures (approximately each photo represents $1 \mathrm{~cm}^{2}$ of sample) with a short description of AAMs based on ghiara and metakaolin with different percentage of $\mathrm{NaOH}$ (x-axis) and metakaolin (y-axis). Map results evidenced by different colours (green: positive and whiteout carbonates crystallization; yellow: passed the test but crystallization occurred; red failed test). (Color figure online) 
Literature data concerning the mechanical compressive test of AAMs show "higher" values in mechanical strength due to the larger size of the specimens. The proposed preliminary tests for the mechanical properties used very small samples which are highly affected by defect and, eventually, by the air bubbles entrapped in the paste during the mixing. Therefore, assuming the distribution of these defects as constant in the large samples, we expect much higher compressive strength during tests according to norm UNI EN 826 (Thermal insulating products for building applications-determination of compression behavior).

\section{Conclusion}

The large volume of volcanic residues suggested that these materials might be used for the development of new AAM thanks to their suitable alumina and silica ratio and availability in the large amorphous fraction.

The experimental results demonstrated that these materials are suitable for the consolidation via alkali activation if cured at high temperatures while at room temperature only the mixture with appropriate quantities of metakaolin attained products that satisfy the integrity test showing consolidation. Furthermore, the respective amounts of $\mathrm{NaOH}$ and metakaolin that avoided the appearance of efflorescence were identified. The choice to optimize the composition instead of curing at high temperature is due to application proposed as mortars for restoration which provide the use directly on site.

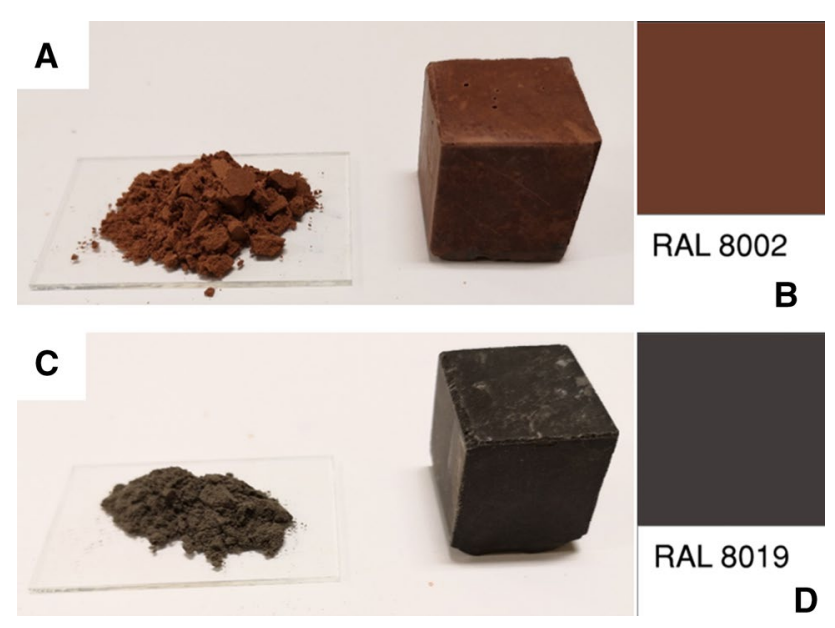

Fig. 14 Chromatic comparison between the volcanic raw materials and the respective AAMs with the colour classification (RAL). Legenda: a ghiara raw material and representative sample belonging to GM1 series; b Colour card (RAL 8002) corresponding to signal brown; $\mathbf{c}$ volcanic ash raw material and representative sample belonging to VM1 series; b Colour card (RAL 8019) corresponding to grey brown. (Color figure online)
The consolidated AAM will be valorised in the restoration work of historical Catania city-centre with the original volcanic raw materials in an innovative way, to overcome the common degradation forms such as detachment or plaster crumbling, observable in important Baroque buildings. Indeed, considering the historical widely use of ghiara in Catania architecture, it was tested for the first time in alkaline synthesis, and in the other hand, AAMs based on volcanic ash were used as comparative elements. The results obtained concerning integrity test in water and the study of efflorescence occurring after air exposition leave us significant hope for applications in restoration field. Moreover, the chromatic aspects, essential parameters in Cultural Heritage field, between volcanic raw materials with the respective AAMs produced demonstrate a good compatibility, confirmed by the comparison with the colour classification ("Reichsausschuss für Lieferbedingungen"-RAL) which showed the following affinities: RAL 8019 for AAMs based on volcanic ash and RAL 8002 for AAMs based on ghiara (Fig. 14). Moreover, in terms of mechanical strengths, AAMs are directly proportional to metakaolin used as additive, influencing also the density, workability, microstructure and water absorption. An increase of cumulative pore volume in the range size $0.1-0.01 \mu \mathrm{m}$ (contrary to $100-1 \mu \mathrm{m}$ ) in the samples aged one year than the standard ones was recorded, confirming the improving of durability properties with time due to on-going geopolymerization and gel production which fills up the voids of the gel matrix resulting in a more homogeneous and denser pore-structure with time as observed in [28].

Finally, the use of volcanic wastes for AAMs production can contribute to solve the problem of their storage in dedicated areas during the emergency state occurring immediately after effusive eruptions.

Acknowledgements Authors are particularly grateful to Balco company of Sassuolo, Italy, for providing the metakaolin and to Dr. Braga, Ingessil, Montorio, Verona, Italy, for useful discussion on formulation and preparation of sodium silicate solution and also we would like to thank Dr. Musarra, who supplied us ghiara raw material. Moreover, this research was supported by the AGM for CuHe project (PNR fund with code: ARS01_00697; CUP E66C18000380005).

Open Access This article is licensed under a Creative Commons Attribution 4.0 International License, which permits use, sharing, adaptation, distribution and reproduction in any medium or format, as long as you give appropriate credit to the original author(s) and the source, provide a link to the Creative Commons licence, and indicate if changes were made. The images or other third party material in this article are included in the article's Creative Commons licence, unless indicated otherwise in a credit line to the material. If material is not included in the article's Creative Commons licence and your intended use is not permitted by statutory regulation or exceeds the permitted use, you will need to obtain permission directly from the copyright holder. To view a copy of this licence, visit http://creativecommons.org/licenses/by/4.0/. 


\section{References}

1. Prentice, J.E.: Geology of Construction Materials. Springer, Amsterdam (1990)

2. Andreozzi, L.: La lava, l'uomo e l'architettura. Il Lunario, EnnaItaly (2003)

3. Mazzoleni, P.: The use of volcanic stone in architecture: example of Etnean region. Acta Vulcanol. 18, 141-144 (2007)

4. Barone, G., Mazzoleni, P.: Le lave. Lexicon. Storie e Archit. Sicil. 14-15, 69 (2012)

5. Belfiore, C.M., La Russa, M.F., Mazzoleni, P., Pezzino, A., Viccaro, M.: Technological study of "ghiara" mortars from the historical city centre of Catania (Eastern Sicily, Italy) and petrochemical characterisation of raw materials. Environ. Earth Sci. 61, 995-1003 (2010). https://doi.org/10.1007/s12665-009-0418-5

6. Barone, G., Mazzoleni, P., Corsaro, R.A., Costagliola, P., Di Benedetto, F., Ciliberto, E., Gimeno, D., Bongiorno, C., Spinella, C.: Nanoscale surface modification of Mt. Etna volcanic ashes. Geochim. Cosmochim. Acta 174, 70-84 (2016). https:// doi.org/10.1016/j.gca.2015.11.011

7. Contrafatto, L.: Recycled Etna volcanic ash for cement, mortar and concrete manufacturing. Constr. Build. Mater. 151, 704-713 (2017). https://doi.org/10.1016/j.conbuildmat.2017.06.125

8. Shi, C., Qian, J.: High performance cementing materials from industrial slags - a review. Resour. Conserv. Recycl. (2000). https ://doi.org/10.1016/S0921-3449(99)00060-9

9. Liu, Y., Shi, C., Zhang, Z., Li, N.: An overview on the reuse of waste glasses in alkali-activated materials. Resour. Conserv. Recycl. 144, 297-309 (2019). https://doi.org/10.1016/j.resco nrec.2019.02.007

10. Poinot, T., Laracy, M.E., Aponte, C., Jennings, H.M., Ochsendorf, J.A., Olivetti, E.A.: Beneficial use of boiler ash in alkali-activated bricks. Resour. Conserv. Recycl. (2018). https://doi.org/10.1016/j. resconrec.2017.09.013

11. Polettini, A., Pomi, R., Carcani, G.: The effect of $\mathrm{Na}$ and Ca salts on MSWI bottom ash activation for reuse as a pozzolanic admixture. Resour. Conserv. Recycl. (2005). https://doi.org/10.1016/j. resconrec.2004.07.004

12. Miltiadis, S.K., Giannopoulou, I., Tahir, M.F.M., Hashim, M.F.A., Panias, D.: Upgrading copper slags to added value fire resistant geopolymers. Waste Biomass Valoriz. (2019). https://doi. org/10.1007/s12649-019-00666-1

13. Labrincha, J.A., Marques, J.I., Hajjaji, W., Senff, L., Zanelli, C., Dondi, M., Rocha, F.: Novel inorganic products based on industrial wastes. Waste Biomass Valoriz. 5, 385-392 (2014). https:// doi.org/10.1007/s12649-013-9281-4

14. Millán-Corrales, G., Magallanes-Rivera, R.X., González-López, J.R., Zaldivar-Cadena, A.A., Figueroa-Torres, M.Z.: Synthesis of an alternative hydraulic binder by alkali activation of a slag from lead and zinc processing. Waste Biomass Valoriz. (2018). https:// doi.org/10.1007/s12649-018-0363-1

15. Lancellotti, I., Ponzoni, C., Bignozzi, M.C., Barbieri, L., Leonelli, C.: Incinerator bottom ash and ladle slag for geopolymers preparation. Waste Biomass Valoriz. 5, 393-401 (2014). https:// doi.org/10.1007/s12649-014-9299-2

16. Yadollahi, M.M., Benli, A., Demirbola, R.: The effects of silica modulus and aging on compressive strength of pumice-based geopolymer composites. Constr. Build. Mater. 94, 767-774 (2015). https://doi.org/10.1016/j.conbuildmat.2015.07.052

17. Yankwa Djobo, J.N., Elimbi, A., Kouamo Tchakouté, H., Kumar, S.: Mechanical properties and durability of volcanic ash based geopolymer mortars. Constr. Build. Mater. 124, 606-614 (2016). https://doi.org/10.1016/j.conbuildmat.2016.07.141

18. Duxson, P., Fernández-Jiménez, A., Provis, J.L., Lukey, G.C., Palomo, A., Van Deventer, J.S.J.: Geopolymer technology: the current state of the art. J. Mater. Sci. 42, 2917-2933 (2007). https ://doi.org/10.1007/s10853-006-0637-z

19. Komnitsas, K., Zaharaki, D.: Geopolymerisation: a review and prospects for the minerals industry. Miner. Eng. 20, 1261-1277 (2007). https://doi.org/10.1016/j.mineng.2007.07.011

20. Djobo, J.N.Y., Elimbi, A., Tchakouté, H.K., Kumar, S.: Volcanic ash-based geopolymer cements/concretes: the current state of the art and perspectives. Environ. Sci. Pollut. Res. 24, 4433-4446 (2017). https://doi.org/10.1007/s11356-016-8230-8

21. Provis, J.L., Van Deventer, J.S.J.: Geopolymers: Structure, Processing, Properties and Industrial Applications. Woodhead, Oxford (2009)

22. Glukhovsky, V.D.: Soil Silicate Articles and Structures (Gruntosilikatnye vyroby I konstruktsii). Budivelnyk Publisher, Kiev (1967)

23. Singh, P.S., Bastow, T., Trigg, M.: Structural studies of geopolymers by $29 \mathrm{Si}$ and 27Al MAS-NMR. J. Mater. Sci. 40, 3951-3961 (2005). https://doi.org/10.1007/s10853-005-1915-x

24. Kamseu, E., Leonelli, C., Perera, D.S., Melo, U.C., Lemougna, P.N.: Investigation of volcanic ash based geopolymers as potential building materials. Int. Ceram. Rev. 58, 136-140 (2009)

25. Tchakoute Kouamo, H., Mbey, J.A., Elimbi, A., Kenne Diffo, B.B., Njopwouo, D.: Synthesis of volcanic ash-based geopolymer mortars by fusion method: effects of adding metakaolin to fused volcanic ash. Ceram. Int. 39, 1613-1621 (2013). https:// doi.org/10.1016/j.ceramint.2012.08.003

26. Lemougna, P.N., Wang, K.T., Tang, Q., Nzeukou, A.N., Billong, N., Melo, U.C., Cui, X.: Review on the use of volcanic ashes for engineering applications. Resour. Conserv. Recycl. 137, 177-190 (2018). https://doi.org/10.1016/j.resconrec.2018.05.031

27. Albitar, M., Mohamed Ali, M.S., Visintin, P., Drechsler, M.: Durability evaluation of geopolymer and conventional concretes. Constr. Build. Mater. 136, 374-385 (2017). https://doi.org/10.1016/j. conbuildmat.2017.01.056

28. Gunasekara, C., Law, D.W., Setunge, S.: Long term permeation properties of different fly ash geopolymer concretes. Constr. Build. Mater. 124, 352-362 (2016). https://doi.org/10.1016/j. conbuildmat.2016.07.121

29. Schmid, R.: Descriptive nomenclature and classification of pyroclastic deposits and fragments-recommendations of the IUGS subcommission on the systematics of igneous rocks. Geol. Rundschau. 70, 794-799 (1981). https://doi.org/10.1007/BF01822152

30. Stewart et al.: Protocol for analysis of volcanic ash samples for assessment of hazards from leachable elements June 2013 Report Contents. (2013)

31. Lancellotti, I., Ponzoni, C., Barbieri, L., Leonelli, C.: Alkali activation processes for incinerator residues management. Waste Manag. 33, 1740-1749 (2013). https://doi.org/10.1016/j.wasma n.2013.04.013

32. Toby, B.H., Von Dreele, R.B.: GSAS-II: the genesis of a modern open-source all purpose crystallography software package. J. Appl. Crystallogr. 46, 544-549 (2013). https://doi.org/10.1107/ S0021889813003531

33. Gualtieri, A.F., Zanni, M.: Quantitative determination of crystalline and amorphous phase in traditional ceramics by combined Rietveld-RIR method. Mater. Sci. Forum. 278-281, 834-839 (1998). https://doi.org/10.4028/www.scientific.net/ MSF.278-281.834

34. Corsaro, R.A., Métrich, N.: Chemical heterogeneity of Mt. Etna magmas in the last $15 \mathrm{ka}$. Inferences on their mantle sources. Lithos 252-253, 123-134 (2016). https://doi.org/10.1016/j.litho s.2016.02.006

35. Kani, E.N., Allahverdi, A.: Effect of chemical composition on basic engineering properties of inorganic polymeric binder based on natural pozzolan. Ceram. Silikaty. 53, 195-204 (2009)

36. Bondar, D., Lynsdale, C.J., Milestone, N.B., Hassani, N., Ramezanianpour, A.A.: Effect of heat treatment on reactivity-strength of 
alkali-activated natural pozzolans. Constr. Build. Mater. 25, 40654071 (2011). https://doi.org/10.1016/j.conbuildmat.2011.04.044

37. Robayo-salazar, R.A., Gutiérrez, R.M.D.: Natural volcanic pozzolans as an available raw material for alkali-activated materials in the foreseeable future: a review. Constr. Build. Mater. 189, 109118 (2018). https://doi.org/10.1016/j.conbuildmat.2018.08.174

38. Davidovits, J.: Geopolymers_-inorganic polymeric new materials. J. Therm. Anal. 37, 1633-1656 (1991). https://doi.org/10.1007/ BF01912193

39. Alehyen, S., Achouri, M.E.L., Taibi, M.: Characterization, microstructure and properties of fly ash-based geopolymer. J. Mater. Environ. Sci. 8, 1783-1796 (2017)

40. Van Riessen, A., Rickard, W.D.A., Williams, R.P., Van Riessen, G.A.: Methods for geopolymer formulation development and microstructural analysis. J. Ceram. Sci. Technol. 8, 421-431 (2017). https://doi.org/10.4416/JCST2017-00065

41. Criado, M., Fernández-Jiménez, A., de la Torre, A.G., Aranda, M.A.G., Palomo, A.: An XRD study of the effect of the $\mathrm{SiO}_{2} /$ $\mathrm{Na}_{2} \mathrm{O}$ ratio on the alkali activation of fly ash. Cem. Concr. Res. 37, 671-679 (2007). https://doi.org/10.1016/j.cemconres.2007.01.013

42. Angel, R.J., Carpenter, M.A., Finger, L.W.: Structural variation associated with compositional variation and order-disorder behaviour in anorthite-rich feldspars. Am. Miner. 75, 150-162 (1990)

43. Harlow, G.E.: The anorthoclase structures: the effects of temperature and composition. Am. Miner. 67, 975-996 (1982)

44. Clark, J.R., Appleman, D.E., Papike, J.: Crystal-chemical cheracterization on clinopyroxenes based on eight new structure refinements. Miner. Soc. Am. Spec. Pap. 2 50, 31-50 (1969)

45. Nord, A.G., Annersten, H., Filippidis, A.: The cation distribution in synthetic Mg-Fe-Ni olivines. Am. Miner. 67, 1206-1211 (1982)

46. Greaves, $\mathrm{C}$.: A powder neutron diffraction investigation of vacancy ordering and covalence in $\gamma-\mathrm{Fe}_{2} \mathrm{O}_{3}$. J. Solid State Chem. 49, 325333 (1983). https://doi.org/10.1016/S0022-4596(83)80010-3

47. Gualtieri, A.F., Venturelli, P.: In situ study of the goethite-hematite phase transformation by real time synchrotron powder diffraction. Am. Miner. 84, 895-904 (1999). https://doi.org/10.2138/ am-1999-5-624

48. Gualtieri, A.F.: Accuracy of XRPD QPA using the combined Rietveld-RIR method. J. Appl. Crystallogr. 33, 267-278 (2000). https://doi.org/10.1107/S002188989901643X

49. Porcher, F., Souhassou, M., Dusausoy, Y., Lecomte, C.: The crystal structure of a low-silica dehydrated NaX zeolite. Eur. J. Miner. 11, 333-343 (1999). https://doi.org/10.1127/ejm/11/2/0333

50. Gramlich, V., Meier, W.M.: The crystal structure of hydrated NaA: a detailed refinement of a pseudosymmetric zeolite structure. Zeitschrift fur Krist. New Cryst. Struct. 133, 134-149 (1971). https://doi.org/10.1524/zkri.1971.133.133.134

51. Wadoski-Romeijn, E., Armbruster, T.: Topotactic transformation and dehydration of the zeolite gismondine to a novel $\mathrm{Ca}$ feldspar structure. Am. Miner. 98, 1988-1997 (2013). https://doi. org/10.2138/am.2013.4495

52. Markgraf, S.A., Reeder, R.J.: High-temperature structure refinements of calcite and magnesite. Am. Miner. 70, 590-600 (1985)

53. Wyckoff, R.W.G.: The structure of crystals. Cryst. Struct. 1, 239444 (1963)

54. Yankwa Djobo, J.N., Elimbi, A., Tchakouté, H.K., Kumar, S.: Mechanical activation of volcanic ash for geopolymer synthesis: effect on reaction kinetics, gel characteristics, physical and mechanical properties. RSC Adv. 6, 39106-39117 (2016). https ://doi.org/10.1039/c6ra03667h

55. Obonyo, E.A., Kamseu, E., Lemougna, P.N., Tchamba, A.B., Melo, U.C., Leonelli, C.: A sustainable approach for the geopolymerization of natural iron-rich aluminosilicate materials. Sustainability 6, 5535-5553 (2014). https://doi.org/10.3390/su6095535

56. Tchakoute, H.K., Elimbi, A., Yanne, E., Djangang, C.N.: Utilization of volcanic ashes for the production of geopolymers cured at ambient temperature. Cem. Concr. Compos. 38, 75-81 (2013). https://doi.org/10.1016/j.cemconcomp.2013.03.010

57. Garcia-Lodeiro, I., Palomo, A., Fernández-Jiménez, A., MacPhee, D.E.: Compatibility studies between N-A-S-H and C-A-S-H gels. Study in the ternary diagram $\mathrm{Na}_{2} \mathrm{O}-\mathrm{CaO}-\mathrm{Al}_{2} \mathrm{O}_{3}-\mathrm{SiO}_{2}-\mathrm{H}_{2} \mathrm{O}$. Cem. Concr. Res. 41, 923-931 (2011). https://doi.org/10.1016/j.cemco nres.2011.05.006

58. Bakharev, T.: Geopolymeric materials prepared using Class $\mathrm{F}$ fly ash and elevated temperature curing. Cem. Concr. Res. 35, 1224-1232 (2005). https://doi.org/10.1016/J.CEMCO NRES.2004.06.031

59. Provis, J.L., Lukey, G.C., Van Deventer, J.S.J.: Do geopolymers actually contain nanocrystalline zeolites? A reexamination of existing results. Chem. Mater. 17, 3075-3085 (2005). https://doi. org $/ 10.1021 / \mathrm{cm} 050230 \mathrm{i}$

60. Najafi, E., Allahverdi, A., Provis, J.L.: Cement \& concrete composites efflorescence control in geopolymer binders based on natural pozzolan. Cem. Concr. Compos. 34, 25-33 (2012). https://doi. org/10.1016/j.cemconcomp.2011.07.007

61. Lemougna, P.N., MacKenzie, K.J.D., Jameson, G.N.L., Rahier, H., ChinjeMelo, U.F.: The role of iron in the formation of inorganic polymers (geopolymers) from volcanic ash: a 57Fe Mössbauer spectroscopy study. J. Mater. Sci. 48, 5280-5286 (2013). https:// doi.org/10.1007/s10853-013-7319-4

62. Muthu Kumar, E., Ramamurthy, K.: Influence of production on the strength, density and water absorption of aerated geopolymer paste and mortar using Class F fly ash. Constr. Build. Mater. 156, 1137-1149 (2017). https://doi.org/10.1016/j.conbuildma t.2017.08.153

Publisher's Note Springer Nature remains neutral with regard to jurisdictional claims in published maps and institutional affiliations.

\section{Affiliations}

\section{Germana Barone $^{1}$. Claudio Finocchiaro ${ }^{1} \cdot$ Isabella Lancellotti ${ }^{2}(\mathbb{0}) \cdot$ Cristina Leonelli $^{2} \cdot$ Paolo Mazzoleni $^{1}$. Caterina Sgarlata ${ }^{2} \cdot$ Antonio Stroscio $^{1}$}

Isabella Lancellotti

isabella.lancellotti@unimore.it

Paolo Mazzoleni

pmazzol@unict.it

1 Dipartimento di Scienze Biologiche, Geologiche e Ambientali, Università di Catania, Corso Italia, 57, 95127 Catania, Italy
2 Dipartimento di Ingegneria "Enzo Ferrari”, Università di Modena e Reggio Emilia, Via Pietro Vivarelli 10, 41125 Modena, Italy 